April 2015

\title{
The Civil Rights of Sexually Exploited Youth in Foster Care
}

Dale Margolin Cecka

University of Richmond School of Law

Follow this and additional works at: https://researchrepository.wvu.edu/wvlr

Part of the Civil Rights and Discrimination Commons, Family Law Commons, Juvenile Law Commons, and the Law and Race Commons

\section{Recommended Citation}

Dale M. Cecka, The Civil Rights of Sexually Exploited Youth in Foster Care, 117 W. Va. L. Rev. (2015).

Available at: https://researchrepository.wvu.edu/wvlr/vol117/iss3/13

This 2015 Mid-Atlantic People of Color Conference is brought to you for free and open access by the WVU College of Law at The Research Repository @ WVU. It has been accepted for inclusion in West Virginia Law Review by an authorized editor of The Research Repository @ WVU. For more information, please contact ian.harmon@mail.wvu.edu. 


\title{
THE CIVIL RIGHTS OF SEXUALLY EXPLOITED YOUTH IN FOSTER CARE
}

\author{
Dale Margolin Cecka*
}

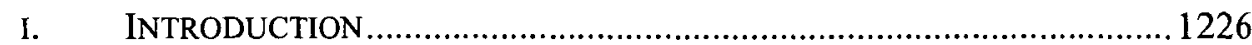

II. THE DEMOGRAPHICS OF ADOLESCENTS IN FOSTER CARE...................1227

A. Adolescents Currently in Foster Care .......................................1227

B. Adolescents Missing from Foster Care ........................................1229

C. The Disproportionality of Adolescents of Color in Foster Care .1234

D. Projections Regarding Minority Adolescents in Foster Care...... 1237

III. THE SEXUAL EXPLOITATION OF ADOLESCENTS IN FOSTER CARE.......1238

A. Sexual Exploitation of Youth in the United States ........................1239

B. Sexual Exploitation of Adolescents in Foster Care ......................1242

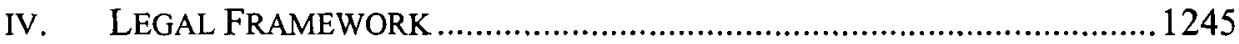

A. Adolescents in Foster Care Are in State Custody.......................1245

1. Federal Law: Title IV-E Foster Care ...................................1245

2. State Law Regarding Adolescents in Foster Care..................1248

B. Recent Legislation Addressing Sexual Exploitation .....................1249

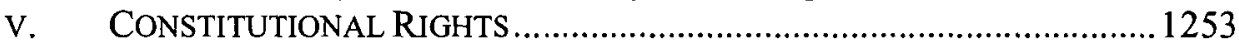

A. The Foster Child's Right To Be Free from Harm While in

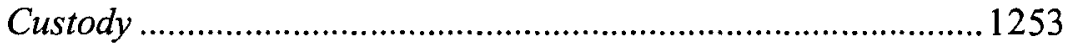

1. Case Law Regarding Foster Children .....................................1253

2. Case Law Regarding Analogous Populations ..........................1258

i. Pretrial Detainees and Prisoners ................................... 1258

ii. Involuntarily Committed Adults.......................................1259

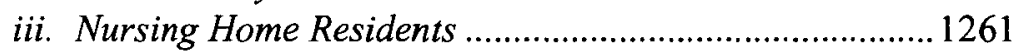

B. The Foster Child's Right To Be Free from Harm when Missing. 1261

C. The Foster Child's Right To Be Free from Harm Following

Discharge-Analogy to State-Created Danger Cases .................. 1266

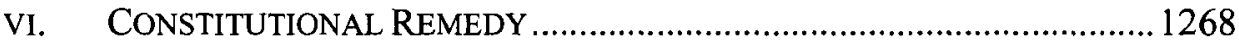

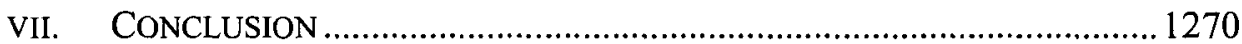

* Clinical Professor of Law and Director, Family Law Clinic, University of Richmond School of Law. J.D., Columbia University, 2004; B.A., Stanford University, 1999. The Author would like to thank Allison Linscott for her invaluable contributions to this Article. 


\section{INTRODUCTION}

Elizabeth Smart may be a household name, but the names of the thousands of foster children currently missing from our child welfare system are unknown to the American public and even to some of the agencies legally responsible for their care. Each year, vast numbers of these young people, who are predominantly children of color, become victims of sexual exploitation while in the custody of the state or shortly after their planned release. At this rate, and given population trends, the number of sexually exploited youth with a history of foster care will climb to close to half a million in the next generation. ${ }^{1}$

The plight of these young people raises a unique legal question: Do state and contract agencies bear any liability for this exploitation? Foster children are in a unique position vis-à-vis the Constitution. They are wards of the state but actually fare worse in federal courts than prisoners and institutionalized adults, in terms of their right to be free from harm while in custody. To be fair, it is not easy to monitor foster children; they are statutorily entitled to the least restrictive foster care placement, as they should be. But every effort should be made to ensure that they go unscathed. Too often, as a result of institutional indifference, older foster youth are harmed due to a lack of commitment to addressing their needs.

Even if it were well settled that the state owes a unique duty to foster children, would this duty extend to youth who have absconded from custody and been lured into "criminal" activity? What about youth who have been discharged, but to precarious situations that put them at foreseeable risk? Recent federal legislation regarding the sexual exploitation of foster youth demonstrates political concern on the national stage, but the laws have no teeth. Our states and localities do not actually invest in this population; nor do our federal or state lawmakers hold anyone accountable for what happens to adolescents while they are in the foster care system or following discharge. Are we finally ready to hold child welfare agencies accountable for what happens to foster children when they are missing or discharged from the system? Could federal courts address this epidemic?

Constitutional law regarding prisoners, institutionalized adults, and the residents of nursing homes suggests that it is time for the judiciary to step in. The civil rights of other populations have not been addressed from the ground up without court intervention. Unless we hold state agencies accountable, they will never fully address the needs of adolescents in foster care; nor will they truly revolutionize their service models to provide client-centered services that actually work. Litigation is necessary in order to effectuate foster children's rights and realize actual reform in the child welfare system.

1 See infra notes 104, 137; see also infra Part II for an explanation of this projection. 
This paper examines the civil rights of youth who are missing or discharged from foster care and become victims of sexual exploitation. It also addresses future implications of this epidemic, given demographic patterns of the United States, if we do not address this issue now. Section II describes the demographics of adolescents in foster care. Next, Section III addresses the sexual exploitation of this population. Section IV describes the legal framework of the foster care system and legislation pertaining to sexually exploited youth. Section $\mathrm{V}$ analyzes the constitutional rights of foster youth who become victims of sexual exploitation and draws analogies to similarly situated groups whose rights have been more firmly established by federal courts. Finally, Section VI concludes that adolescents in foster care have a constitutional right to be free from state action which puts them at risk for sexual exploitation.

\section{THE DEMOGRAPHICS OF ADOLESCENTS IN FOSTER CARE}

\section{A. Adolescents Currently in Foster Care}

Even though children in foster care are technically in the custody of the state and each one should be accounted for, it is difficult to gauge precise numbers of adolescents in foster care because of well-documented challenges in the child welfare system. ${ }^{2}$ These include, "poor monitoring[;] . . inadequate policies, training, and supervision; lack of effective decision making tools and safety assessment protocols; and poor tracking systems, along with high caseloads that limit the time available for visiting with families and documenting cases," according to the Child Welfare League of America. ${ }^{3}$

Close to half of the children in foster care in the United States are adolescents. In 2012, 46\% were preteenagers and teenagers (11 and older); ${ }^{4}$ youth ages 16 and older make up approximately $19 \%$ of all children in foster care. ${ }^{5}$ The vast majority of these youth will be discharged by the state to their own legal custody, which is commonly referred to as being discharged to "independent living." This means that at age 18, 19, or 21 (depending on state

2 Caren Kaplan, Child Welfare league of AM., Children Missing from Care: AN ISSUE BRIEF ix (2014), available at http://66.227.70.18/programs/fostercare/childmiss01.pdf.

Id.

Children's Bureau, U.S. Dep't of Health \& Human Servs., The AFCARS Report; PRELIMINARY FY 2012 ESTIMATES AS OF NOV. 20131 (2013) [hereinafter AFCARS Nov. REPORT], available at http://www.acf.hhs.gov/sites/default/files/cb/afcarsreport20.pdf.

Id; see also LAUREN EySTER \& SARAH LOONEY OLDMIXON, NGA CENTER FOR BEST Practices, Issue Brief: State Policies To Help Youth Transition Out of Foster Care 2 (2007), available at http:/www.nga.org/files/live/sites/NGA/files/pdf/0701 YOUTH.PDF.

6 Young. People Leave Foster Care to a Family, JIM CASEY YouTH OPPORTUNITIES INITIATIVE, http://www.jimcaseyyouth.org/young-people-leave-foster-care-family (last visited Apr. 2, 2015) ("Historically, child welfare agencies, having been created to protect children and support families, routinely authorized permanency plans of 'independent living' for older youth 
law) the youth are on their own, not the legal responsibility of any caring adult. ${ }^{7}$ This is also known as "aging out of foster care."

Aging out is on the rise, despite efforts to eliminate "independent living" as a foster care goal. ${ }^{8}$ According to numerous studies, approximately 30,000 young people officially age out of foster care each year in the United States. ${ }^{9}$ Since 1999 , more than 230,000 young people have been discharged from foster care without a permanent family to go home to; ${ }^{10}$ more than 165,000 from 1998 to $2005 .^{11}$ Most importantly, during this same seven-year period (1998 to 2005, which is the last period for which aggregate data is available), the percentage of all foster children who age out steadily increased each year, and as of 2005 , stood at $4.9 \%$. $^{12}$ Some states have shocking percentages of youth who age out-Virginia leads the pack, with $21 \%$ of the state's entire foster care population aging out, and Maine is close behind with

in foster care."); see also John Kelly, APPLA: The Foster Care Exception That Ate the Rule, THE CHRON. OF SOC. ChANGE (Aug. 15, 2013), https://chronicleofsocialchange.org/analysis/appla-thefoster-care-exception-that-ate-the-rule/3756 ("Among youths that had reached 17 in foster care ... close to half had APPLA as an expected outcome."); AFCARS NOV. REPORT, supra note 4 (stating that $21 \%$ of children in foster care had a goal other than adoption or reunification, including goals of emancipation and long-term foster care); Jennifer Renee \& Gerald P. Mallon, Unpacking the No of Permanency for Youth: Overuse and Misuse of APPLA, THE HANDBOOK OF Child Welfare, Practices, Policies and Programs (Columbia Univ. Press 2014), available at http://www.nrcpfc.org/as-training/download/33.Renne.APPLA.Final.03.16.2012.pdf (stating that in some states the goal of "long term foster care" is only available for a child over 12 years of age, so all of the children with that goal are adolescents and will age out of foster care).

7 Fostering Connections to Success and Increasing Adoptions Act of 2008, Pub. L. No. 110$351, \S 201$ (a), 122 Stat. 3949, 3957-58 (giving states the option of keeping 18-year-olds in foster care); CAL. WELF. \& INST. CODE $\S 303$ (2013) (extending the age of foster care to 21 in California); VA. CODE ANN. § 63.2-600 (2014).

8 Adoption and Safe Families Act of 1997 (ASFA), Pub. L. No. 105-89, 111 Stat. 2115 (The five permissible ASFA permanency plans are: return to parent; adoption; referral for legal guardianship; permanent placement with a fit and willing relative; another planned permanent living arrangement (but only if there is a compelling reason why none of the other ASFA permanency plans is in the child's best interests)). For a discussion of foster care goals, see infra Part III.

9 Foster Care Resource Center, CHILDREN's ACTION NETWORK, http://childrensaction network.org/resources.html (last visited Apr. 2, 2015).

10 Aging Out, JiM CASEY YouTh OPPORTUNITIES INITIATIVE, http://www.jimcaseyyouth.org/ about/aging-out (last visited Apr. 2, 2015).

11 The Pew Charitable Trusts, Time for Reform: AgINg OUt ANd ON Their OWn 1 (2007) [hereinafter TIME FOR REFORM], available at http://www.pewtrusts.org/ /media/legacy/uploaded files/wwwpewtrustsorg/reports/foster_care_reform/KidsareWaitingTimeforReform0307pdf.pdf; Research, AGING OUT INSTITUTE, http://agingoutinstitute.com/research-3 (last visited Apr. 2, 2015) [hereinafter Research].

12 TIME FOR REFORM, supra note 11. 
$19 \% .{ }^{13}$ Thirteen other states all age at least $10 \%$ of their foster children out of foster care. ${ }^{14}$

In fact, thousands of youth currently in foster care have been assigned goals by their state agencies that are essentially the same as independent living, but with new names, such as "emancipation" or "long-term foster care." 15 These permanency goals indicate that child welfare officials no longer focus on seeking families or other supportive adults to help transition these older youths from foster care. In 2005, approximately 32,000 adolescents had a goal of "emancipation," and more than 37,000 had a goal of "long term foster care."16 These 69,000 youths, and those that have followed in the past nine years, were on a path to leave foster care without a permanent family to count on. ${ }^{17}$

\section{B. Adolescents Missing from Foster Care}

Another estimated 30,000 youths age out of the foster care system but are not officially counted by the state as discharged, because they run away or are otherwise unable to be located by the state. ${ }^{18}$ Child welfare professionalscaseworkers, social workers, therapists, lawyers, and judges-routinely refer to runaways from foster care as Absent Without Leave, or "AWOL." This language speaks to the impersonal and implicitly punitive nature of the system. Children who run away from their family homes are never called AWOL by anyone, even when they appear in court or at an institution such as a shelter. This Article does not use this negative terminology; instead, in line with other studies, the Article includes as "missing" foster children all those who have either left care voluntarily (i.e., run away) or involuntarily (i.e., been abducted) and/or cannot otherwise be accounted for by the agency responsible for their placement (i.e., lost in care).$^{19}$

It is extremely difficult to ascertain precise numbers of missing foster children because inherently, these children are lost and state and local authorities have no incentive to report them as such or acknowledge that they have lost track of their wards. In fact, there are no provisions in the federal legislation governing foster $\operatorname{care}^{20}$ that specifically address the prevention,

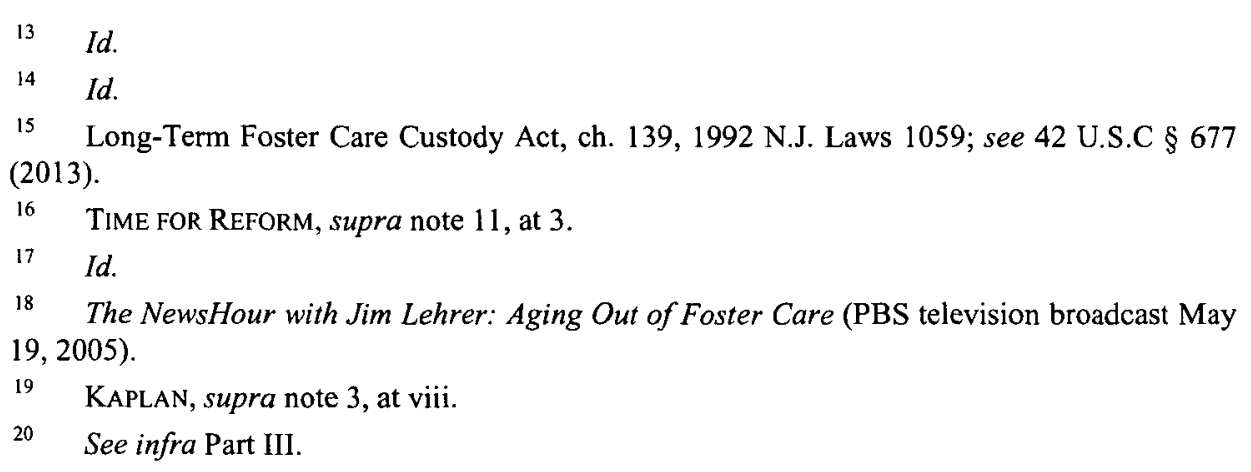


response to, or resolution of missing episodes. ${ }^{21}$ Caseworkers are not required to report missing foster children to the National Center for Missing and Exploited Children (NCMEC), the agency whose federal mandate ${ }^{22}$ is to work in partnership with the U.S. Department of Justice to help states find missing children (including foster children), eliminate child sexual exploitation, and prevent child victimization. Although state agencies make reports to the federal government, ${ }^{23}$ the federal government does not follow up on what happens to these children or on whether these numbers are accurate. ${ }^{24}$ Moreover, each state has its own internal reporting and classification systems for youth who run; ${ }^{25}$ some do not classify "runaways" at all, ${ }^{26}$ One thing we know for sure: $61 \%$ of homeless 18- and 19-year-olds have been in foster care at some point. ${ }^{27}$

No national numbers are available regarding the number of youth who run away from foster care. ${ }^{28}$ However, data from the Adoption and Foster Care Analysis and Reporting System (AFCARS) ${ }^{29}$ collected by the federal government indicate that on September 30, 2009, 8,047 foster youth were on

21 Shannon Wilber et al., CWLA Best Practice Guidelines 10 (2006) [hereinafter CWLA], available at http://familyproject.sfsu.edu/sites/sites7.sfsu.edu.familyproject/files/best practiceslgbtyouth.pdf.

$22 \quad 42$ U.S.C. $\$ 5773$ (2013); see Congressional Authorization, NAT'L CENTER FOR MISSING AND EXPLOITED CHILD., http://www.missingkids.com/Authorization (last visited Dec. 23, 2014) [hereinafter Congressional Authorization]. A summary of NCMEC's duties include: operating a national 24-hour toll-free telephone line by which individuals may report information regarding the location of any missing child and assisting the efforts of law enforcement agencies in coordinating with child welfare agencies to respond to foster children missing from the state welfare system. They also provide technical assistance to law enforcement agencies and first responders in identifying, locating, and recovering victims of, and children at risk for, child sex trafficking. Id.

23 Children's Bureau, U.S. Dep'T of Health \& Human Servv., The AFCARS Report: PRELIMINARY FY 2009 EsTIMATES AS OF JULY 2010 I (2013) [hereinafter AFCARS JULY REPORT], available at http://www.acf.hhs.gov/sites/default/files/cb/afcarsreport 17.pdf.

24 CWLA, supra note 21 . There are no provisions in federal foster care law which specifically address or require states to report missing foster children, nor are there any that require the federal government to track missing foster children. Id.

25 Michael Pergamit \& Michelle Ernst, Running Away from Foster Care: Youth's KNOWLEDGE AND ACCESS OF SERVICES 8 (2011), available at http://www.1800runaway.org/ assets/1/7/NORC_Part_C_Final.pdf.

26 Id.; Todd Wallack, Hundreds May Be Missing in Child Welfare System, Boston GLoBE (Feb. 27, 2014), available at http://www.bostonglobe.com/2014/02/27/hundreds-kids-maymissing-state-welfare-system/t5qc84Uzd8LWiphMl5ecFP/story.html.

27 LEGAL CTR. FOR Foster CARE \& EDUC., What CHILD Welfare AdVOCATES CAN DO FOR UNACCOMPANIED YOUTH (2008) [hereinafter WeLFARE ADVOCATES], available at http://center. serve.org/nche/downloads/child_wel_uy.pdf.

28 PERGAMIT \& ERNST, supra note 25.

29 AFCARS JULY REPORT, supra note 23. 
runaway status. ${ }^{30}$ Significantly, $5.5 \%$ of the youths ages 14 to 17 in placement were on runaway status; ${ }^{31}$ roughly $8 \%$ of all 17 -year-olds were on runaway status. ${ }^{32}$ Because these counts were taken on a single day, they underestimate the percentage of youth who may have run away at some time during that year or during their entire time in foster care. ${ }^{33}$ Also, individual states (and counties) have different practices for categorizing a child as a runaway. ${ }^{34}$ For example, according to state records, there were zero 17 -year-olds on runaway "status" in New Hampshire on September 30, 2009, but in Texas, 17.4\% of all 17-yearolds were on runaway status. ${ }^{35}$ Eleven states and the District of Columbia do not use "runaway" as a reason for official discharge, but in Oregon, $17.2 \%$ of children are discharged as runaways. ${ }^{36}$ It is impossible, therefore, to know how much of the disparity in runaway "rates" is due to real differences in youth behavior and how much is due to different coding practices. ${ }^{37}$ However, according to this wildly inconsistent data, of all youths discharged from care during $2009,2 \%$ were discharged due to being on runaway status; ${ }^{38} 3.5 \%$ of all 17 -year-olds were discharged as runaways. ${ }^{39}$

There are also a significant number of minors who should be taken in to custody by a state's child welfare system after being kicked out or running away from home, but who, for various reasons, are not picked up. These youths fall through the cracks for two primary reasons:

First, child welfare agencies often hesitate to take custody of older youth. Appropriate placements are scarce, and achieving permanency is challenging. Second, many unaccompanied youth strive to avoid entering the child welfare system, due to loyalty to parents, fear of retribution against themselves or siblings, unwillingness to relinquish control over their lives, or mistrust of the child welfare system. ${ }^{40}$

A U.S. Department of Health and Human Services study found that $46 \%$ of homeless youth left their family's home (not foster home) because of physical

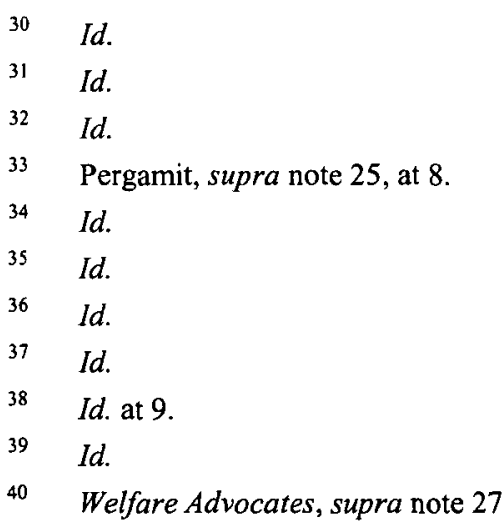


abuse; $17 \%$ left because of sexual abuse. ${ }^{41}$ Over $50 \%$ of young people in shelters and on the streets report that their parents told them to leave or knew they were leaving and did not care. ${ }^{42}$ Each year, 1.6 to 1.7 million youths run away or are forced out of their homes by their parents or other caretakers. ${ }^{43}$

As far as raw numbers regarding foster children who are missing or have run away, the only data available are from sporadic reports in newspapers and independent investigations. In 2002, Michigan acknowledged that it had lost track of 302 foster children. ${ }^{44}$ In the 1990s, New York City recorded an average of 4,000 runaways from foster care per year. ${ }^{45}$ Florida acknowledged 648 missing children in $2006 .{ }^{46}$ But, again, these are inherently underestimates; they only include children classified by state governments as "runaways," and, as noted, some states do not even use this classification. ${ }^{47}$ It does not count all the children the state cannot physically locate at any given point in time.

Studies by Non-Governmental Organizations (NGOs) indicate higher raw numbers of runaway and missing foster children than the individual state and city accounts discussed above. The Vera Institute in New York City found that of those youths who first enter foster care as adolescents, $40 \%$ had at least one reported "missing" child during their time in care. ${ }^{48}$ According to another study, $46 \%$ of 17 -year-olds in foster care in Illinois, Iowa, and Wisconsin reported having run away at some time $;^{49}$ in Illinois alone, the rate was $52 \%{ }^{50}$ Nearly two-thirds of those who ran away did so more than once. ${ }^{51} \mathrm{~A}$ similar

4111 Facts About Homeless Teens, DoSOMETHING.ORG, https://www.dosomething.org/facts/ 11 -facts-about-homeless-teens (last visited Dec. 24, 2014).

$42 \quad I d$.

43 Welfare Advocates, supra note 27.

44 Jack Kresnack, Reporting Holds Michigan's Child Welfare System Accountable, NEIMAN REP. (June 15, 2004), http://niemanreports.org/articles/reporting-holds-michigans-child-welfaresystem-accountable/.

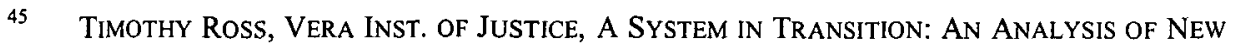
YORK CITY'S FOSTER CARE SYSTEM AT THE YEAR 2000 (2001), available at http://www.vera.org/ sites/default/files/resources/downloads/All_Exec_Summaries.pdf.

46 Who's Looking for Foster Care's Lost Children, ABC NEws (June 4, 2006), http://abc news.go.com/WNT/FosterCare/story?id=2038588.

$47 \quad$ Id.

48 Marni Finklestein, Vera Inst. of Tech., Youth Who Chronically aWOL from Foster Care: Why They Run, Where They Go, and What Can Be Done 3 (2004), available at http://www.vera.org/sites/default/files/resources/downloads/Foster_AWOLs.pdf.

49 PERGAMIT \& ERNST, supra note 25, at 1 (citing MARK E. COURTNEY ET AL., MidWEST Evaluation of Adult Functioning of Former Foster Youth: Conditions of Youth PreParing To Leave State Care (2004), available at http://www.chapinhall.org/sites/default/ files/ChapinHallDocument_8.pdf).

so $\quad$ Id. 
study of 17-year-olds in Los Angeles foster care found $36 \%$ had run away from care at least once. $^{52}$

According to a 2013 article in The Oklahoman, children in a foster care shelter are free to leave at any time and "if the child is above the age of 15 , or sometimes if they are above the age of 13 and 'seem particularly mature,' the shelter staff will not follow the child nor will the police be called." 53 "The National Runaway Safeline has found that less than one-quarter of youths are in touch with their caseworker while on a runaway episode. ${ }^{5}$

The National Runaway Safeline's research also indicates that youths are both literally and figuratively overlooked by caseworkers. According to their field work, youth who run away want to see their families more often and believe that more needs to be done to obviate the effects of being placed away from their neighborhood, family, and friends. ${ }^{55}$ The foster youth they interviewed reported a strong desire for someone to talk to, someone who will listen to them and help work through problems. ${ }^{56}$ The youths felt that caseworkers do not provide the support they need and that caseworkers should visit more often. ${ }^{57}$ According to the study, most youths do not hate the system or blame it for having to remove them from their home; they just want it to work better. 58

The Vera Institute conducted research which underscores why so many children stay away after they run.

Youths returning to foster care after an AWOL may not be able to return to the foster home they left, either because foster parents will not take them back or because a group home filled their beds if they were gone for more than three days. For the youth, losing their bed may mean staying the night at an emergency placement facility, registering in a new school, and developing relationships with new caregivers and housemates. $^{59}$

\footnotetext{
52 Id. (citing Michael R. Pergamit \& Heid Johnson, Extending Foster Care Age to 21: IMPLICATIONS AND ESTIMATES FROM YOUTH AGING OUT OF Foster CARE IN LOS ANGELES (2009).

53 Conna Craig, Protect Foster Children from Sex Trafficking, USA TODAY (Oct. 23, 2013), http://www.usatoday.com/story/opinion/2013/10/23/children-sex-trade-foster-care-column/3153 $537 \%$.

54 NAT'L RUNAWAY SAFELINE, http://www.1800runaway.org/learn/research/why_they_run/ foster_fact_sheet/ (last visited Dec. 23, 2014).

55 Id.

$56 \quad I d$.

$57 \quad$ Id.

$58 \quad$ Id.

59 Finkelstein, supra note 48, at 1.
} 
Despite the numbers and consequences of runaways, the Vera Institute and The National Runaway Safeline are some of the only organizations that have actually studied the issue in depth and, most importantly, surveyed youth themselves. According to the Child Welfare League of America, the field has "a dearth of research on children missing from" out-of-home care-or even promising practices-"in the prevention of, response to, and resolution of missing from care episodes." ${ }^{11}$ This is indicative of the overall indifference to this population.

\section{The Disproportionality of Adolescents of Color in Foster Care}

Unlike figures on runaways, the disproportionality of minority children in the foster care system has been well documented and studied. ${ }^{62}$ In 2008, of the estimated 399,546 children in foster care, 54\% were Black, Hispanic, or Multiracial. ${ }^{63}$ During the same time, only $37 \%$ of the general population was Black, Hispanic, or Multiracial. ${ }^{64}$ The U.S. Department of Health and Human Services reported in 2003 that although black children accounted for $15 \%$ of the total child population, they made up $25 \%$ of victims in substantiated cases of child maltreatment and $45 \%$ of children in foster care. ${ }^{65}$ American Indian children compose $2 \%$ of the foster care population, nearly double their rate in the general population. ${ }^{66}$ According to the official data, Hispanic children are slightly overrepresented in child welfare, making up $20 \%$ of children in care. ${ }^{67}$

60 Child Welfare league of AM., Children Missing from Care: Proceedings of the EXPERT PANEL MEETING 7 (Mar. 8-9, 2004), available at http://66.227.70.18/programs/fostercare/ childmissmtg.pdf.

$61 \quad I d$. at 4.

62 See, e.g., U.S. Gov'T ACCOUNTABILITY OfFICE, GAO-07-816, AFRICAN AMERICAN CHILDREN IN FOSTER CARE (2007), available at http://www.gao.gov/assets/270/263615.pdf;

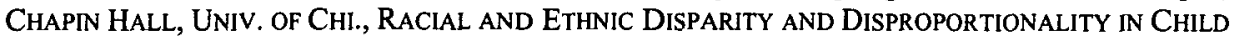
WELFARE AND JUVENILE JUSTICE (2009) [hereinafter RACIAL AND ETHNIC DISPARITY], available at http://cjjr.georgetown.edu./pdfs/cjjr_ch_final.pdf; Disproportionate Representation of Children and Youth of Color, NAT'L RESOURCE CENTER FOR PERMANENCY AND FAM. CONNECTIONS, http://www.hunter.cuny.edu/socwork/nrcfcpp/info_services/disproportionate.html (last visited Apr. 16, 2015).

63 Child Welfare Info. Gateway, AdDressing Racial Disproportionality in Child WELFARE (2011) [hereinafter ADDRESSING RACIAL DISPROPORTIONALITY], available at http://www.childwelfare.gov/pubPDFs/racial_disproportionality.pdf.

64 Eric Kayne, Census: White Majority in U.S. Gone by 2043, NBC News (June 13, 2014, 4:11 AM), http://usnews.nbcnews.com/_news/2013/06/13/1893411 1-census-white-majority-inus-gone-by-2043?lite.

65 RACIAL AND ETHNIC DISPARITY, supra note 62, at 13.

66 Id.

67 ADDRESSING RACIAL DISPROPORTIONALITY, supra note 63. 
There are also indications that Hispanic children are coming into care at faster rates than other children. ${ }^{68}$

The system's racial imbalance is most apparent in big cities where there are sizeable minority and foster care populations, ${ }^{69}$ and importantly for this Article, where prostitution rings predominate. "I0 "In Chicago, for example, $95 \%$ of children in foster care are black." 71 "Out of 42,000 children in New York City's foster care system at the end of 1997, only 1,300 were white."72 Black children in New York were ten times as likely as white children to be in state protective custody. ${ }^{73}$ This imbalance is remarkable in states with high black or other minority populations. For example, $50 \%$ of North Carolina's foster care population is black. ${ }^{74}$ In Minnesota, Native American children make up a shocking $12 \%$ of the foster care population; in Kansas, Nebraska, Montana, South Dakota, Utah, Washington, and Wisconsin, Native American children make up between $4 \%$ and $7 \%$ of the general population. ${ }^{75}$

According to the federal government's own studies, there are no statistically significant differences in overall maltreatment rates between African American and Caucasian families. ${ }^{76}$ Disturbingly, children and families of color are treated differently at all points in the child welfare system. ${ }^{77}$ Research shows that families of color, when compared with Caucasian families, have less contact with child welfare workers, receive fewer services, and are

Susan W. Downs, Child Welfare and Family Services: Policies and Practice (6th ed. 2000); Sandra Stukes Chipungu \& Tricia B. Bent-Goodley, Meeting the Challenges of Contemporary Foster Care, 14 CHILD., FAM. \& Foster CARE 1, 79 (2004) (citing CHILDREN'S Bureau, U.S. Dep't of Health \& Human Servs., The AFCARS Report: Preliminary Fy $2003(2003)$ ).

69 Dorothy Roberts, Race and Class in the Child Welfare System, FronTLINE, http://www.pbs.org/wgbh/pages/frontline/shows/fostercare/caseworker/roberts.html (last visited Apr. 2, 2015).

70 U.S. Dep't of Justice, The National Strategy for Child Exploitation Prevention AND INTERDICTION 33 (2010), available at http://www.justice.gov/psc/docs/natstrategyreport.pdf.

$71 \quad$ Roberts, supra note 69.

72 Id.

$73 \quad I d$.

74 African American Children in Foster Care, CHILD. SERVICES PRAC. NOTES FOR N.C. CHILD WELFARE WORKERS, May 2001, at 1, available at http://www.practicenotes.org/vol6_no2/cspn\% 20v6_2.pdf.

75 Alicia Summers et al., Disproportionality Rates for ChILdREN OF COLOR IN FOSTER CARE TeChNICAL ASSISTANCE BUlletin 3-4 (2013), available at http://www.ncjfcj.org/sites/ default/files/Disproportionality $\% 20$ Rates $\% 20$ for $\% 20$ Children $\% 20$ of $\% 20$ Color $\% 20$ in $\% 20$ Foster \%20Care\%202013.pdf.

76 See Casey family Programs, Disproportionality in the Child Welfare System 1 (2006) [hereinafter Disproportionality IN THE CHILD Welfare SySTEM], available at http://www.ncsl.org/print/cyf/fostercarecolor.pdf. 
substantially less likely to receive services in their homes. ${ }^{78}$ The children themselves receive fewer familial visits, fewer contacts with caseworkers, fewer written case plans, and fewer developmental or psychological assessments. ${ }^{79}$

Of most significance to this Article, black children are placed in foster care at twice the rate of white children. ${ }^{80}$ Instead of being referred to foster care, $72 \%$ of Caucasian children are served in their homes, while only $40 \%$ of Hispanic/Latino children and $44 \%$ of African American children receive inhome services. ${ }^{81}$ Two recent studies measured African American to white placement disparity among children of different age groups in different regions and found that disparity increased for teens over time across all areas; in other words, black adolescents across the nation are placed in foster care at the highest rates. ${ }^{82}$ Once in foster care, the median length of stay for black children is $80 \%$ longer, with an average stay of 18 months as compared to 10 months for white children ${ }^{83}$ African American children also experience substantially more moves while in foster care as compared to Caucasian children. ${ }^{84}$

African American children are also less likely than children of other races to be reunited with their families. ${ }^{85}$ Five major studies in the 1990 s, and one in 2005, led to the same conclusion: that Caucasian children are reunited with their families at four times the rate of African American children ${ }^{86}$ This analysis found race continued to be a strong predictor of reunification, even after controlling for other factors: age of entry, parental job skills, parental substance abuse problems, and services provided to caretaker ${ }^{87}$ One study also

78 Id. (citing Dorothy E. Roberts, RaCial Disproportionality IN THE U.S. Child Welfare System: Documentation, Research on Causes, and Promising Practices (2002), available at $\mathrm{http}: / / \mathrm{www}$.familyandchildwellbeing.com/images/Minority_Overrepresentation_in_ Child_Welfare_-_Dorothy_Roberts_AECF_Paper.pdf).

79 Id. (citing RoberT B. HILL, SYNTHESIS OF RESEARCH ON DisProportionality IN CHILD WELFARE: AN UPDATE (2006), available at http://www.cssp.org/publications/child-welfare/ alliance/synthesis-of-research-on-disproportionality-robert-hill.pdf).

80 Children's Bureau, U.S. Dep'T of Health \& Human Servs., The AFCars Report: PRELIMINARY FY 2003 ESTIMATES AS OF JUNE 2006 (2006), available at www.hhs.gov/sites/ default/files/cb/afcarsreport10.pdf.

81 DisPROPORTIONALITY IN THE CHILD WELFARE SYSTEM, supra note 76, at 2.

82 Fred Wulczyn \& Bridgette Lery, Chapin Hall, UNiv. OF Chi., Racial Disparity in FOSTER CARE ADMISSIONS (2007), available at http://www.chapinhall.org/sites/default/files/old_ reports/399.pdf.

83 DisPROPORTIONALITY IN THE CHILD WELFARE SYSTEM, supra note 76, at 2.

84 Id. (citing Children's Bureau, U.S. Dep't of Health \& Human Servs., Safety, Permanency \& Well-Being ChILd Welfare OUtComes (1999)).

85 Id.

$86 \quad I d$.

$87 \quad$ Id. 
demonstrated that children of color, particularly African American children, who are legally available for adoption wait longer to be adopted. ${ }^{88}$

Older children of color in foster care also seem to receive fewer independent living services care. Of 98,561 youth receiving independent living services in 2011 , the majority of these young adults were white, $32 \%$ were African American, and 20\% were Hispanic. ${ }^{89}$ All of these factors-fewer reunification services, longer stays in foster care, slower adoptions, and less access to independent living resources-contribute to the crises facing adolescents of color aging out of care ${ }^{90}$ and in particular to their vulnerability to sexual exploitation.

\section{Projections Regarding Minority Adolescents in Foster Care}

According to the latest U.S. Census, for the first time, America's racial and ethnic minorities now make up about half of the under-five age group. ${ }^{91}$ Fueled by immigration and high rates of birth, particularly among Hispanics, whites have already fallen to a minority among babies. ${ }^{92}$ The government also projects that in five years, minorities will make up more than half of children under $18 .^{93}$ The fastest percentage growth is among multiracial Americans, followed by Asians and Hispanics. Non-Hispanic whites make up 63\% of the United States; Hispanics, 17\%; blacks, $12.3 \%$; Asians, 5\%; and multiracial Americans, $2.4 \% .{ }^{94}$ About $40 \%$ of whites age 25 to 29 graduate from college, compared with $15 \%$ for Latinos and $23 \%$ for blacks. " "More so than ever, we need to recognize the importance of young minorities for the growth and vitality of our labor force and economy,' said William H. Frey, a demographer at the Brookings Institution who analyzed the census data." 96

In terms of the child welfare system, the percentage of Hispanics in foster care increased by $1 \%$ from 2009 to 2010 , and has held steady at $21 \%$ for the past three years. ${ }^{97}$ Also significant, "Non-Hispanic multiple race groups"

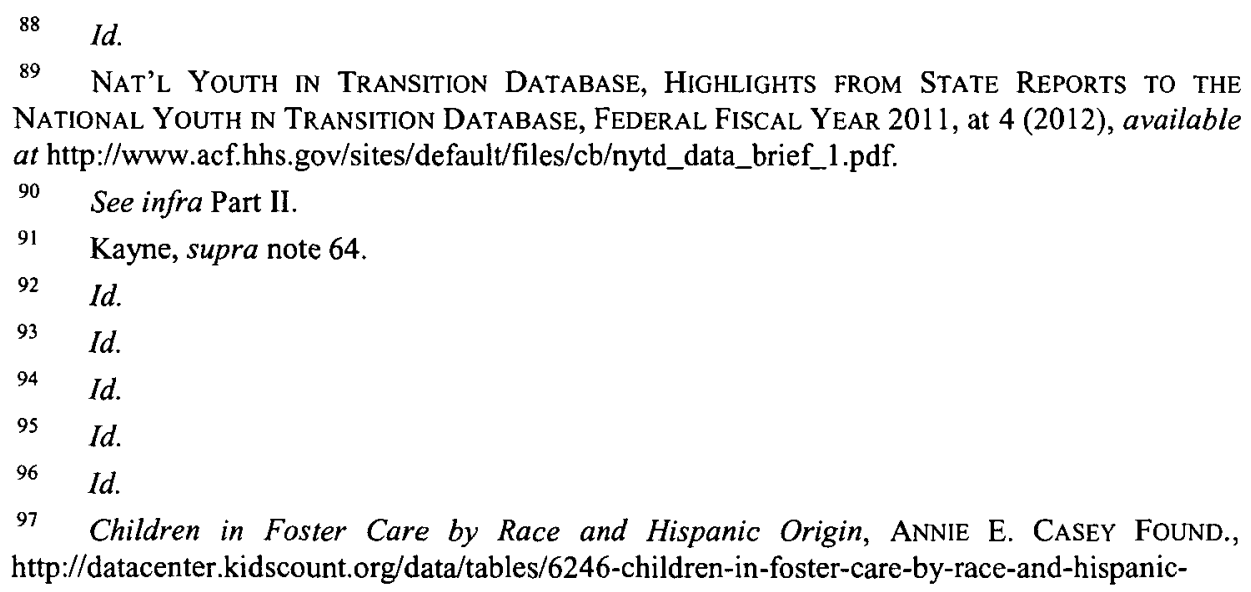


and "race unknown" children have each increased by $1 \%$ since 2008 , and have remained at $6 \%$ and $3 \%$ respectively. ${ }^{98}$ This has serious implications for the make-up of foster care in the next generation.

There are also implications of these population changes in foster care for the next decade. According to the AFCARS, Hispanic children make up $23 \%$ of the population waiting to be adopted, which means that if they are not, they will age out of care as adolescents in the near future. ${ }^{99}$ Unknown and multiple race children make up $9 \%$ and Native American $2 \%$ of the population waiting to be adopted, all out of proportion to their populations in foster care rolls. ${ }^{100}$ If these children do not get adopted, which is increasingly unlikely as they get older, ${ }^{101}$ they will be out on their own before they know it and certainly before they are ready.

\section{The SeXual EXPloitation of Adolescents IN Foster CARE}

Adolescents in foster care face heartbreaking futures. ${ }^{102}$ In particular, shocking numbers of children become victims of sexual exploitation while in the custody of the state or shortly after planned discharge. Caseworkers, judges, and lawyers know this tragic truth all too well from their daily practices.

origin?loc=1 \&loct=1\#detailed/1/any/false/868,867,133,38,35/2638,2601,2600,2598,2603,2597,2 602,1353/12992,12993 (last visited Apr. 2, 2015).

$98 \quad$ Id.

99 AFCARS NOV. REPORT, supra note 4.

$100 \quad I d$

101 N. Am. Council on Adoptable Children, IT's Time to MaKe Older Child Adoption a Reality: BeCAuse EVERY CHILd AND YOUTH DESERVES A FAMILY 1 (2009), available at http://www.nacac.org/adoptalk/MakeOlderChildAdoptionReality.pdf.

102 The tragic outcomes of youths aging out of foster care have been well documented and will not be detailed here. These outcomes include extremely high rates of homelessness, unemployment, incarceration, failure to finish high school or college, and early pregnancy. See, e.g., Lucy A. Bllarer \& Mark E. Courtney, Nat'l Campaign to Prevent Teen Pregnancy, SCIENCE SAYS Research Brief No. 27: Foster CARE Youth 2 (2006), available at https://the nationalcampaign.org/sites/default/files/resource-primary-download/ss27_fostercare.pdf; TIME FOR REFORM, supra note 11; Midwest Evaluation of the Adult Functioning of Former Foster Youth, CHAPIN HALL, UNIV. OF CHI., http:/www.chapinhall.org/research/report/midwestevaluation-adult-functioning-former-foster-youth (last visited Dec. 30, 2014).

103 Josh Kovner, Out of the Shadows: Sex-Trafficking a Threat to Runaway Connecticut Teens, HARTFORD CURRENT (Dec. 14, 2014), http://www.courant.com/news/connecticut/hc-childtrafficking-exploitation-p-1214-20141212-story.html?track=rss\#page=1; Elissa Nadworny, FBI, Social Workers Unite To Attack Sexual Trafficking of Children, SACRAMENTO BEE (June 3, 2014), http://www.sacbee.com/news/nation-world/article2600436.html. 


\section{A. Sexual Exploitation of Youth in the United States}

An estimated 300,000 to 400,000 children are sexually exploited every year in the United States. ${ }^{104}$ The most frequent age of entry into commercial sex industry in the United States is 12 years old. ${ }^{105}$ The overwhelming majority of these youth have run away or been kicked out ("throwaways") of their homes or foster care placement. ${ }^{106}$ According to the U.S. Department of Health and Human Services, in 1999, 1,682,900 youths had a period of time in which they could be characterized as a runaway or throwaway youth; $71 \%$ of these youth were considered at risk for prostitution. ${ }^{107}$ One in three teens will be recruited by a pimp within 48 hours of leaving home, ${ }^{108}$ and one out of three homeless teens do, in fact, resort to prostitution. ${ }^{109}$

It is extremely difficult to count raw numbers of sexually exploited youth. ${ }^{110}$ There is wide disparity among police reports, social service

104 See Michelle Lillie, OLP Foundation \& HumanTraffickingSEARCh.NET, AN UNHOLY alliance: The Connection Between Foster Care and Human Trafficking 2 (2013), available at http://digitalcommons.unl.edu/humtrafcon5/4/; Child Trafficking and Sexual Exploitation of Children, THORN (Feb. 21, 2014), http://www.wearethorn.org/child-traffickingexploitation-in-the-united-states/; William Adam et al., Juvenile Justice Bulletin: Effects of Federal Legislation on the Commercial Sexual Exploitation of Children, OFF. OF JUV. JUST. AND DELINQ. PREVENTION (July 2010), https://www.ncjrs.gov/pdffiles1/ojjdp/228631.pdf; OFFICE OF JUST. PROGRAMS, http://ojp.gov/newsroom/factsheets/ojpfs_humantrafficking.html (last visited Apr. 2, 2015).

lo5 Nat'l Sexual Violence Res. CTr., Housing, Homelessness, and Sexual Violence STATISTICS, available at http://www.nsvrc.org/sites/default/files/NSAC11_Handouts/NSACl1_ Handout_With_Statistics.pdf; Protecting Vulnerable Children: Preventing and Addressing Sex Trafficking of Youth in Foster Care: Hearing Before the H. Comm. on Ways and Means, 113th Cong. (2013) (testimony of John D. Ryan, Chief Executive Officer, The National Center for Missing \& Exploited Children).

106 One study estimates $30 \%$ of shelter youth and $70 \%$ of street youth are victims of commercial sexual exploitation; they engage in or are coerced into prostitution for "survival sex" to meet daily needs for food, shelter, or drugs. See RiChard J. Estes \& NeIl Alan WeInER, CTR. for the Study of Youth Pol'y, The Commercial Sexual Exploitation of Children in the U.S., Canada, AND Mexico 131 (2001); see also J. M. Greene et al., Prevalence and Correlates of Survival Sex Among Runaway and Homeless Youth, 89 AM. J. PUB. 1406, 1406 (1999).

107 Heather J. Clawson et al., U.S. Dep't of Health \& Human Servs., Human Trafficking into and Within the United States: A Review of the Literature (2009), available at http://aspe.hhs.gov/hsp/07/humantrafficking/litrev/.

108 Housing, Homelessness, AND SEXUAL VIOLENCE STATISTICS, supra note 105.

109 CASE Campaign Against Sexually Exploitation, NAT'L CTR. FOR THE ProseCUTION OF CHILD ABUSE, http://www.ndaa.org/ncpca_case_campaign.html/(last visited Nov. 25, 2014).

110 Michelle Stransky \& David Finelhor, Crimes Against Children Research Ctr., How Many Juveniles ARe Involved in Prostitution IN THE U.S.? (2008), available at http://www.unh.edu/ccrc/prostitution/Juvenile_Prostitution_factsheet.pdf; see also DEBORAH Boyer, City of Seattle Human Servs. Div., Who Pays the Price?: Assessment of Youth 
observations, and global estimates; ${ }^{111}$ prostitution is clandestine and universally under-reported. ${ }^{112}$ A 2008 report in Seattle found that 300 to 500 children were involved in prostitution in the Seattle/King County area. ${ }^{113}$ In New York City, estimates are even higher at 2,200 youths being commercially sexually exploited. ${ }^{114}$ Arrest numbers are also shocking considering they only take into account youth who have been found by police and are reasonably suspected of prostitution. Furthermore, according to federal law, the Trafficking Victims Protection Act (TVPA) ${ }^{115}$ passed in 2000 , minors are not even supposed to be arrested at all for prostitution by any law enforcement agency in the country. ${ }^{116}$ Despite this, in California, 804 children were arrested for prostitution in the year 2010 and 363 in Texas. ${ }^{117}$

Youth of color make up the majority of sexually exploited minors. In Los Angeles, $38 \%$ of youth under the age of 18 arrested for prostitution-related offenses identified as non-white (primarily African American). ${ }^{18}$ Other research conducted on a subpopulation of exploited minors shows that African American girls and women are arrested in prostitution at a far higher rate than girls and women of other races involved in the same activity. ${ }^{119}$ African American females are also sexually exploited at a younger age on average than other children. $^{120}$ In a Los Angeles study, 92\% of all victims of sexual

INVOLVEMENT IN Prostitution IN SEATtLe (2008), available at http://www.seattle.gov/human services/domesticviolence/Report_YouthInProstitution.pdf.

111 BOYER, supra note 110.

112 STRANSKY \& FINELHOR, supra note 110.

113 BOYER, supra note 110.

114 Ric Curtis et al., U.S. DeP'T Of Justice, 1 The Commercial SeXual Exploitation of CHILDREN IN NEW YORK CITY (2008), available at $\mathrm{https://www.ncjrs.gov/pdffiles1/nij/grants/}$ 225083.pdf.

115 Victims of Trafficking and Violence Protection Act of 2000, Pub. L. No. 106-386, 114 Stat. 1464; Trafficking Victims Protection Reauthorization Act of 2003, Pub. L. No. 108-193, 117 Stat. 2875; Trafficking Victims Protection Reauthorization Act of 2005, Pub. L. No. 109164, 119 Stat. 3562; Trafficking Victims Protection Reauthorization Act of 2008, Pub. L. No. 110-457, 122 Stat. 5044. TVPA states that sex trafficking of children occurs when anyone under the age of 18 is induced to perform a "commercial sex act," which is defined as "any sex act on account of which anything of value is given to or received by any person."

116 CLAWSON, supra note 107.

117 Brenda Zurita, Beverly LaHAye InSt., ChILdRen IN Prostitution (2012), available at http://www.cwfa.org/wp-content/uploads/2013/11/CWA_Decriminalization-of-Prostitution-forMinors2012.pdf.

118 Kamala D. Harris, att'y Gen., Cal. Dep't of Justice, Crime in California 2010 (2010), available at http://ag.ca.gov/cjsc/publications/candd/cd10/preface.pdf?.

119 Clawson, supra note 107 (citing R. BARRI Flowers, THE Prostitution of WOMEN AND GIRLS (1998)).

120 Kate Walker, Cal. Child Welfare Council, Ending the Commercial Sexual Exploitation of Children: A Call for Multi-System Collaboration in California 19 
exploitation identified as African American. ${ }^{121}$ According to another study of all reported trafficking cases, $21 \%$ of victims identified as Hispanic. ${ }^{122}$

Females make up the overwhelming majority of those exploited; a 2011 report by the Bureau of Justice Statistics on the characteristics of suspected human trafficking incidents stated that almost $95 \%$ of sex trafficking victims were female. ${ }^{123}$ Young girls are also much more likely to be arrested for prostitution-one study found that girls under the age of 18 were over 14 times more likely to be arrested for prostitution than their male peers. ${ }^{124}$

One reason, relevant to this Article, that young women are so much more likely to become sexually exploited than males is that it has been well documented that females in foster care are more likely to run away. ${ }^{125}$ Moreover, national studies have shown that $75 \%$ of all runaways are female. ${ }^{126}$ However, male runaways from foster care and from home are also at high risk for sexual exploitation, particularly those who identify as LGBTQ. The primary reason is that LGBTQ youth are overrepresented in the homeless youth population. $^{127}$

Data collection on this population has been difficult for a number of reasons; many youth do not self-disclose their sexual orientation or gender identity out of fear of harassment and/or discrimination, many providers harbor bias against LGBTQ youth, do not question youth about their identities,

(2013), available at http://www.youthlaw.org/fileadmin/ncyl/youthlaw/publications/EndingCSEC-A-Call-for-Multi-System_Collaboration-in-CA.pdf.

121 Chelsea Parsons et al., 3 Key Challenges in Combating the Sex Trafficking of Minors in the United States, CTR. FOR AM. Progress (Apr. 8, 2014), available at https://www.american progress.org/issues/lgbt/report/2014/04/08/87293/3-key-challenges-in-combating-the-sex-traffic king-of-minors-in-the-united-states/.

122 See id.

123 Commercial Sexual Exploitation of Children/Sex Trafficking, OFF. OF JUV. JUST. \& DELINQ. Prevention, http://www.ojjdp.gov/mpg/litreviews/CSECSexTrafficking.pdf (last visited Apr. 12, 2015).

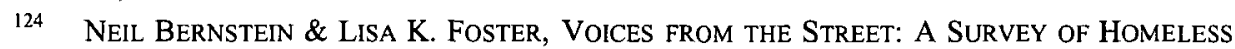
YOUTH BY THEIR PEERS (2008), available at http://www.library.ca.gov/crb/08/08-004.pdf.

125 PERGAMIT \& ERNST, supra note 25, at 5-6.

126 Homeless and Runaway Youth, NAT'L CONF. OF ST. LEGISLATURES (Oct. 10, 2013), http:/www.ncsl.org/research/human-services/homeless-and-runaway-youth.aspx.

127 Andrew Cray et Al., Ctr. for Am. Progress, Seeking Shelter: The Experiences AND UNMET NEEDS OF LGBT HOMELESS YOUTH (2013), available at http:/cdn.americanprogress.org/ wp-content/uploads/2013/09/LGBTHomelessYouth.pdf. 
and/or are not trained in developing trusting relationships with LGBTQ youth. ${ }^{128}$

However, a recent survey reported that about $40 \%$ of homeless youth identify as LGBTQ, identifying that they are homeless because of family rejection due to their sexual orientation or gender identification. ${ }^{129}$ This same report found that more than $40 \%$ of agencies serving homeless youth do not address issues related to this rejection. ${ }^{130}$ Another study uncovered that a disproportionate number of male youth held in detention by police for prostitution identify as gay, bisexual, or questioning; only $1 \%$ of heterosexual boys are detained for prostitution compared with $10 \%$ of their gay, bisexual, or questioning peers. ${ }^{131}$ "Many homeless youth engage in survival sex (exchanging sex for food, shelter, clothing, etc.),"132 and this is particularly common for LGBTQ youths. One study found that LGBTQ "youth were three times more likely to engage in survival sex as compared to their homeless heterosexual counterparts."

\section{B. Sexual Exploitation of Adolescents in Foster Care}

There is an extremely strong correlation between sexual exploitation and involvement with the child welfare system. ${ }^{134}$ First of all, as discussed in

128 Bernadette Brown, The Commercial Sexual Exploitation of LGBTQ Youth, NAT'L CoUNCIL ON CRIME \& DELINQ. (Nov. 26, 2012), http://nccdglobal.org/blog/the-commercial-sexualexploitation-of-lgbtq-youth.

129 Laure E. Durso \& Gary J. Gates, Williams Inst. With True Colors fund and Palette Fund, Serving our Youth: Findings from a National Survey of Service Providers Working with Lesbian, Gay, Bisexual, and Transgender Youth Who are HOMELESS OR AT RISK OF BECOMING HOMELESS 4 (2012), available at http://williamsinstitute. law.ucla.edu/wp-content/uploads/Durso-Gates-LGBT-Homeless-Youth-Survey-July-2012.pdf. Again, this means these youths should be taken in by child welfare.

130 Id.

131 Angela Irvine, "We've Had Three of Them": Addressing the Invisibility of Lesbian, Gay, Bisexual, and Gender Non-Conforming Youth in the Juvenile Justice System, 19 CoLuM. J. GENDER \& L. 675, 694 (2010).

132 BROWN, supra note 128.

133 See id. (citing Nicholas Ray, NAT'L Gay and Lesbian TaSk Force POlicy Inst., Lesbian, Gay, BiseXual and TransGender Youth: AN EPIDEMIC Of HoMELessness (2006)).

134 Michelle Lillie, An Unholy Alliance: The Connection Between Foster Care and Human Trafficking, HuMANTRAFFICKINGSEARCH.NET (Oct. 24, 2013), http://humantraffickingsearch.net/ wp/an-unholy-alliance-the-connection-between-foster-care-and-human-trafficking/ [hereinafter An Unholy Alliance]. See generally U.S. DEP'T OF JUSTICE, supra note 70; Prevention of the Commercial Sexual Exploitation of Foster Children, Young MINDS ADVOCACY PROJECT, http://www.youngmindsadvocacy.org/csec-2/ (last visited Apr. 2, 2015) [hereinafter YouNG MINDS]; Malika Saada Saar, Stopping the Foster Care to Child Trafficking Pipeline, HuFFINGTON Post (Oct. 29, 2013, 5:59 PM), http://www.huffingtonpost.com/malika-saada-saar/stopping-thefoster-care-_b_4170483.html. 
Section II, thousands of children run away from foster care each year, and runaways are susceptible to sexual exploitation. Foster youth are even more susceptible. Children who have been involved with the system are the main target of the criminals seeking children to exploit. ${ }^{135}$ The high correlation of children with a history of abuse and sexual exploitation is also due to a number of risk factors including, "early trauma history, dangerous environments, lack of supportive caregiving, and severe mental health."

According to one study, $98 \%$ of children who are identified as survivors of sex trafficking had previous involvement with child welfare services. ${ }^{137}$ More conservatively, the National Center for Exploited Children reports that $60 \%$ of runaway children who are sexually exploited had involvement with the child welfare system. ${ }^{138}$ Half of the sexually exploited children in California were placed in foster care or a group home at some point in their life. ${ }^{139}$ The percentages are even higher in certain areas of the state. A study in the Bay Area revealed that over $75 \%$ of the sexually exploited youths were victims of abuse or neglect. ${ }^{140}$ Los Angeles reports $61 \%$ of sexually exploited victims were in foster care, and $80 \%$ of the girls had child welfare involvement. ${ }^{141}$ In New York City, $75 \%$ of sexually exploited children were in foster care. ${ }^{142}$

obtain, ${ }^{143}$ we are aware of 14,900 foster youth who were sexually assaulted

135 Young MINDS, supra note 134; see also U.S. DEP'T OF JUSTICE, supra note 70, at 31 ; Kovner, supra note 103 ("Trafficking of children for sex... was, and is, happening in Connecticut, and is as simple as a girl, or even a boy, running away from a foster home or somewhere else and bumping, literally, into a pimp trolling the mall or the park for just such a target.").

136 DANNa Basson et al., WestCoAst Children's Clinic, ResEarCh to ACtion: Sexually EXPLOITED MINORS (SEM) NEEDS AND STRENGTHS 11 (2012), available at http://www.westcoast cc.org/WCC_SEM_Needs-and-Strengths_FINAL.pdf.

137 Sex Trafficking and Exploitation in America: Hearing Before the S. Comm. on Fin., 113th Cong. 2 (2013) (testimony of Joette Katz, Commissioner, Connecticut Department of Children and Families).

138 Preventing and Addressing Sex Trafficking of Youth in Foster Care: Hearing Before the H. Comm. on Ways and Means, 113th Cong. 2 (2013) (testimony of Louise M. Slaughter, United States Rep. from New York).

139 An Unholy Alliance, supra note 134.

140 Kate Walker, Cal. Child Welfare Council, Commercial Sexual Exploitation: The INTERSECTION WITH CHILD WELFARE, available at http://www.courts.ca.gov/documents/BTB_ XXII_IIH_10.pdf.

14! Preventing and Addressing Sex Trafficking of Youth in Foster Care: Hearing Before the H. Comm. on Ways and Means, 113 th Cong. 1 (2013) (testimony of Karen Bass, United States Rep. from California) [hereinafter Bass].

142 LILlE, supra note 104, at 2.

143 STRANSKY \& FINELHOR, supra note 110 , at 1. 
during their time as a runaway. ${ }^{144}$ Also, 1,700 foster children are known to have prostituted in order to receive things such as food, shelter, or drugs. ${ }^{\text {I45 }}$

Sexual exploitation does not only result when children run away from foster care, but also when they age out of care. ${ }^{146}$ Children aging out of foster care become homeless at alarming rates, and, as discussed, all homeless youth are at high risk for sexual exploitation. The National Alliance to End Homelessness reports that $11 \%$ to $37 \%$ of all children aging out of care deal with homelessness and an additional $25 \%$ to $50 \%$ are unstably housed. ${ }^{147}$ The United States Interagency Council on Homelessness reports that within four years of exiting the system, $25 \%$ of children will be homeless. ${ }^{148}$ This is critical because $75 \%$ of all sexually exploited victims report being homeless. ${ }^{149}$ Reports have shown that youth need only be on the street for no longer than seven days before they are at a higher risk of sexual exploitation. ${ }^{150}$ The City of Seattle alone estimates that there are between 700 and 1,000 homeless youth on any given night. ${ }^{151}$ A 1999 report found that $40 \%$ of "persons in federally funded homeless shelters were former foster youth." "I52 In Massachusetts, a 2005 Census of homeless young adults ages 18 through 24 , found that $25 \%$ were former foster care youth. ${ }^{153}$ A California study found that $65 \%$ of former foster care youths age out without secured housing. ${ }^{154}$

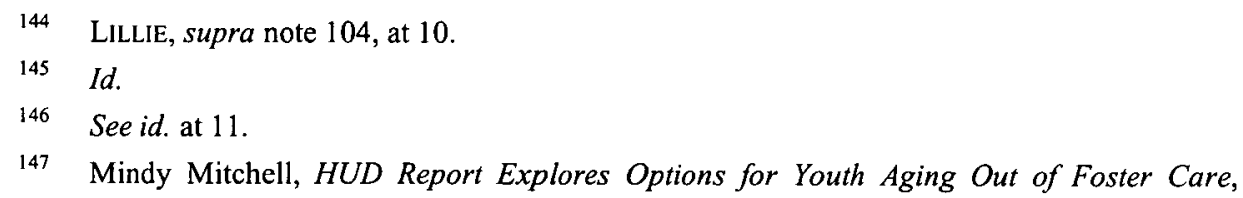
NAT'L ALlianCE TO END HoMELESSNESS (June 2, 2014), http://www.endhomelessness.org/blog/ entry/hud-report-explores-options-for-youth-aging-out-of-foster-care\#.VHTz-VfF9RE.

148 Opening Doors: Homelessness Among Youth, U.S. INTERAGENCY COUNCIL ON HOMELESSNESS, http://usich.gov/usich_resources/fact_sheets/opening_doors_homelessness_ among_youth/ (last visited Feb. 28, 2015).

149 LILLIE, supra note 104, at 11.

150 Nat'l Coal. to Prevent Child Sexual Abuse and Exploitation, National Plan to Prevent the Sexual Abuse and Exploitation of Children 5 (2012), available at http://www.preventtogether.org/Resources/Documents/NationalPlan2012FINAL.pdf.

151 Preventing and Addressing Sex Trafficking of Youth in Foster Care: Hearing Before the $H$. Comm. on Ways and Means, 113 th Cong. 2 (2013) (testimony of Melinda Giovengo, Executive Director, YouthCare).

152 Michele Benedetto, An Ounce of Prevention: A Foster Youth's Substantive Due Process Right to Proper Preparation for Emancipation, 9 U.C. DAVIS J. JUV. L. \& POL'Y 381, 387 (2005).

153 MASS. SOC'Y FOR THE PREVENTION OF CRUElTy to CHILdREN, 18 AND OUT: LifE AfTER FOSTER CARE IN MASSACHUSETTS 13 (2005), available at http://www.chapa.org/sites/default/ files/qwert_16.pdf.

154 Cal. Dep't of Soc. Servs., Report on the Survey of the Housing NeEds of EMANCIPATED FOSTER/PROBATION YOUTH 6 (2002), available at http:/www.childsworld.ca.gov/ res/pdf/rptonthehousingneeds.pdf. 
Youth who have already been discharged from foster care, or who are well aware that they will be kicked out of their group or foster homes the day their foster care check stops coming, are perfect prey for pimps. In the words of the DOJ:

Pimps ... manipulate children into a life of prostitution and then use physical and emotional abuse to keep their victims trapped in that way of life. Pimps target children who are vulnerable to exploitation, including those with low selfesteem, who are runaways or throwaways, and who have histories of physical and sexual abuse. Pimps typically recruit a vulnerable child by first showing affection and attention and promising a stable relationship.... After the child has been manipulated into a relationship with the pimp, the pimp begins training or "seasoning" her by normalizing the life of prostitution and making her completely dependent on him.... To solidify his control, the pimp ... will beat, torture, or starve the child to force her into obedience. Some pimps use alcohol or drugs to control their victims. To manipulate the child, the pimp also uses emotional tactics such as renaming her to break down her identity and telling her that she has no value except as a prostitute. The pimp also separates the child from biological family and friends as well as anything familiar. Additionally, the pimp keeps all of the profit earned by the child and delivers violent punishment if the child withholds any money. The pimp uses a combination of praise and abuse that causes the child to constantly work for his affection. The child becomes completely dependent on the pimp for food, clothing, shelter, and attention. The pimp's control often is so complete that victims are incapable of leaving. ${ }^{155}$

\section{LEGAL FRAMEWORK}

\section{A. Adolescents in Foster Care Are in State Custody}

\section{Federal Law: Title IV-E Foster Care}

A child can only be placed in long-term foster care by court order granting the state physical and legal custody. ${ }^{156}$ State laws and regulations

\footnotetext{
155 U.S. DEP'T OF JUSTICE, supra note 70, at 31-32.

15642 U.S.C. $\S 672(a)(2)(A)(i i)$ (2013) (making "a judicial determination to the effect that continuation in the home from which removed would be contrary to the welfare of the child" a prerequisite for removal and placement into foster care). For a sample of states with similar
} 
govern foster care, with each state having its own unique system. ${ }^{157}$ However, foster care is also regulated and funded at the federal level, primarily by Title IV-E of the Social Security Act. ${ }^{158}$ A state's funding from the federal government is conditioned on providing all children in foster care with certain case management services. ${ }^{159}$ Each child is entitled to a case plan which details their "permanency plan" and the services and care needed to help them achieve that goal. ${ }^{160}$ There are only five possible permanency goals: return to parent, adoption, legal guardianship, permanent placement with a fit and willing relative, and "another planned permanent living arrangement" (APPLA). ${ }^{161}$ APPLA is the category states use when they discharge youth to their own legal custody after turning $18 .{ }^{162}$ No adolescent in foster care can be discharged to their own legal custody before the age of $18 .{ }^{163}$ Under federal law, permanency plans for all adolescents in foster care age 16 and older, regardless of receiving

provisions, see VA. CODE ANN. §63.2-908B (2014) ("A local department or a licensed childplacing agency shall have authority pursuant to a court order to place a child over whom it has legal custody in a permanent foster care placement where the child shall remain until attaining majority or thereafter, until the age of twenty-one years...."); MINN. STAT. $\S 260 C .201(a)(2)$ (2014) ("If the court finds that the child is in need of protection or services or neglected and in foster care, it shall enter an order making any of the following dispositions of the case: . . (2) transfer legal custody to one of the following: (i) a child-placing agency; or (ii) the responsible social services agency. In making a foster care placement for a child whose custody has been transferred under this subdivision, the agency shall make an individualized determination of how the placement is in the child's best interests using the consideration for relatives and the best interest factors in section 260C.212, subdivision 2, paragraph (b) ...."); NEB. REV. STAT. § 43 1307 (2014) ("Each court which has placed a child in foster care shall send to the office (a) a copy of the plan or permanency plan, prepared by the person or court in charge of the child in accordance with section 43-1312, to effectuate rehabilitation of the foster child and family unit or permanent placement of the child and (b) a copy of the progress reports as they relate to the plan or permanency plan, including, but not limited to, the court order and the report and recommendations of the guardian ad litem.").

157 See, e.g., 20 Ill. COMp. Stat. 505 (2014); Cal. Ctr. FOR Research on Women \& Families, Understanding tHe Child Welfare System IN CALIFORNIA (2002), available at http://www.ccrwf.org/pdf/ChildWelfarePrimer.pdf; W. VA. DEP'T OF HEALTH AND HUMAN REs., FOSTER CARE POLICY (2014), available at http://www.wvdhhr.org/bcf/children_adult/foster/ policy/FCPolicyJuly2014.pdf; NYS Law and Regulations, NYSCCC, http://nysccc.org/fostercare/ legal-issues/nys-foster-care-laws-and-regulation/ (last modified Feb. 4, 2015).

158 Adoption Assistance and Child Welfare Act of 1980, Pub. L. No. 96-272, 94 Stat. 500. Foster care is currently authorized by Title IV-E of the Social Security Act, as amended, and implemented under the Code of Federal Regulations. 45 C.F.R. pt. 1355 (2014).

15942 U.S.C. $\$$ 671(a) (2013) ("Requisite features of State plan").

$160 I d . \S \S 671(\mathrm{a})(15)(\mathrm{C}),(\mathrm{E}), 675(1)(\mathrm{E})$ (defining "case plan" to include, among other things, a "permanency plan").

161 Id. $\S 675(5)(\mathrm{C})$.

162 Id. In each of the other goals, the legal custodian is either a biological parent, an adoptive parent, a legal guardian, or relative with legal custody. Id. § 675(2).

163 Id. $\S 675(5)(\mathrm{H})$. 
their permanency plan, must include an independent living and transitioning plan with a written description of the programs and services that will help prepare the child for independence. ${ }^{164}$

Until 2011, states could only claim IV-E reimbursements for children under age 18 , or age 19 if the child was still in school. ${ }^{165}$ The Fostering Connections to Success and Increasing Adoptions Act of 2008 (FCA), ${ }^{166}$ and as amended in $2011,{ }^{167}$ made a number of changes to Title IV-E to address the needs of adolescents in and aging out of foster care. ${ }^{168}$ FCA promotes the extension of foster care beyond 18 and conditions federal funding on ensuring that each adolescent has a coordinated transition plan, including health care, living arrangements, and employment or education plans. ${ }^{169}$ States can seek reimbursement for children up to age 21 who are (1) completing high school or an equivalent program, (2) enrolled in a post-secondary or vocation education program, (3) participating in a program designed to promote or remove barriers to employment, (4) employed at least 80 hours per month, or (5) exempt from the above qualifiers based on medical conditions. ${ }^{170} \mathrm{FCA}$ also provides options that states may elect to improve outcomes for youth in and leaving foster care. $^{171}$

\section{Id. $\$ 675(1)(\mathrm{D})$.}

165 See Child Welfare Policy Manual $\$ 8.3 A$, CHILD. BUREAU, http://www.acf.hhs.gov/cwpm/ programs/cb/laws_policies/laws/cwpm/policy_dsp.jsp?citID $=8$.

166 Pub. L. No. 110-351, 122 Stat. 3949. The Fostering Connections Act also amended other parts of the Social Security Act, including Title IV-B, which authorizes federal funding for certain child welfare services. I am focusing primarily on Title IV-E of the Social Security Act in this Article.

167 H.R. 2883, 112th Cong. (2011). On September 20, 2011, the Child and Family Services Improvement and Innovation Act, reauthorizing Title IV-B of the Social Security Act, was signed into law. Among the many important provisions of the Act, it provides clarification to a critical element of the education stability provisions of the Fostering Connections Act.

168 U.S. Gov't Accountability Office, GAO-14-347, Foster CARE: HHS NeEdS To IMPROVE OVERSIGHT OF FOSTERING CONNECTIONS ACT IMPLEMENTATION 4 (2014) [hereinafter GAO-14-347], available at http://www.gao.gov/assets/670/663655.pdf. See generally May Shin, Note, A Saving Grace? The Impact of the Fostering Connections to Success and Increasing Adoptions Act on America's Older Foster Youth, 9 HASTINGS RACE \& POVERTY L. J. 133 (2012).

169 Eyster \& Looney, supra note 5.

170 Id

171 See GAO-14-347, supra note 168, at 4. Other options include: (1) authorizing states to provide and receive federal reimbursement for some kinship guardianship assistance payments, id.; (2) allowing states to waive on a case-by-case basis non safety licensing standards for relative foster families, id. at 34; (3) authorizing HHS to share information from the Federal Parent Locator Service with child welfare agencies for Title IV-E purposes, id. at 4; (4) authorizing the use of foster care maintenance payments to cover the cost of reasonable travel expenses to enable the child to remain in the school where the child was enrolled at time of placement, id. at 5; (5) allowing extended eligibility for Chafee Foster Care Independence Program Services to youth who exit foster care to adoption or kinship guardianship at age 16 or older, id. at 42 ; and (6) 
A separate federal law, The Chafee Foster Care Independence Act ${ }^{172}$ (Chafee) was passed in 1999 to address the growing crisis of youth aging out of care. ${ }^{173}$ It provides grants to states, apart from their Title IV-E funds, to create programs that support adolescents discharging from foster care. Chafee provides states with "flexible funding" to "enable programs to be designed and conducted" to assist former foster youth. ${ }^{174}$ All states provide some extended services to young people 18 and older; however, the level of services varies dramatically among states. Some states, such as Iowa, provide robust postfoster care services, while others provide very little support. ${ }^{175}$

\section{State Law Regarding Adolescents in Foster Care}

All states receive federal funding for foster care ${ }^{176}$ and are therefore supposed to comply with Title IV-E of the Social Security Act. According to federal law, as discussed above, states cannot release children to themselves (i.e., their own legal custody) until they are at least age $18 .{ }^{177}$ Since the passage of the Fostering Care Connections Act, 24 states now allow adolescents to remain in foster care past age $18,{ }^{178}$ in some cases until age $21 .{ }^{179}$ In states that extend foster care, youth who are discharged to themselves may later reenter

authorizing an extended eligibility for education and training vouchers to youth who exit foster care to kinship guardianship at age 16 or older, id. at 5 .

172 Pub. L. No. 106-169, 113 Stat. 1882 (1999).

173145 Cong. Rec. H12846.01 (daily ed. Nov. 18, 1999) (statement of Rep. Nancy Johnson) ("This bill will provide, for the first time, realistic support for our most unfortunate children, those who have been in foster care for many years and who reach adulthood essentially alone.").

17442 U.S.C. $\$ 677$ (a) (2013).

175 See GAO-14-347, supra note 168, at 12. For an overview on how states have used and enacted this grant to provide education and training programs to former foster youth, see RoBIN Nixon \& Maria Garin Jones, Nat'l Foster Care Coal. \& Casey Family Programs, The Chafee Educational and Training Voucher (ETV) Program: Six States' Experiences (2007), available at http://www.issuelab.org/resource/chafee_educational_and_training voucher_program_six_states_experiences.

176 Title IV-E Foster Care, CHILD. BUREAU (May 17, 2012), http://www.acf.hhs.gov/programs/ $\mathrm{cb} /$ resource/title-ive-foster-care.

17742 U.S.C. $\$ 675(5)(D)$ (2013).

178 Young People Leave Foster Care to a Family, JIM CASEY YouTH OPPORTUNITIES INITIATIVE, http://www.jimcaseyyouth.org/young-people-leave-foster-care-family (last visited Feb. 28, 2015).

179 See Progress in the States, JIM CASEY YouTH OPPORTUNITIES INITIATIVE, http://www.jimcaseyyouth.org/progress-states (last visited Feb. 28, 2015) States have either chosen to allow children over age 18 to remain legally in foster care under all five eligibility conditions described (CA, OR, TX, ND, MN, AR, IL, IN, MI, AL, PA, MD, DC, NY, RI, MA, $\mathrm{ME}$ ), extended foster care under some of the eligibility conditions (TN, WA, WV), or have passed legislation in connection with the Fostering Connections Act and have an extension plan in development (NE, HI, CT). Id. 
care. ${ }^{180}$ The U.S. Department of Health and Human Services' (HHS) instructions implementing the FCA permit states to extend foster care that either permits youth to remain in "care continuously or leave foster care and return ... at some point after attaining age 18," as long as the original court order remains in effect and other IV-E eligibility criteria are satisfied. ${ }^{181}$

\section{B. Recent Legislation Addressing Sexual Exploitation}

In 2014, the sexual exploitation of foster children gained congressional recognition with unanimous passage of H.R. 4980, the Preventing Sex Trafficking and Strengthening Families Act (PSTSF). ${ }^{182}$ "[T] system as a whole has not truly recognized trafficking as a crisis within the foster youth population," said House of Representatives member Karen Bass, a co-chair of the Congressional Caucus on Foster Youth and an original cosponsor of H.R. 4058 , during debate on the Bill. ${ }^{183}$ According to Bass, child welfare case workers have not been adequately trained and prepared to identify or respond to child victims of trafficking. ${ }^{184}$ Further, certain child welfare policies may have unintentional negative effects on the well-being of the children it is meant to protect. ${ }^{185}$ The Bill's cosponsors acknowledged that some foster care regulations inadvertently increase the foster child's isolation and separation from friends, family and the surrounding community, resulting in an increased vulnerability to victimization. ${ }^{186}$

Title I of the Preventing Sex Trafficking Act amends Title IV-E of the Social Security Act by requiring each state to develop policies and procedures for identifying, documenting, and determining appropriate services for any child or youth in care who the state has reasonable cause to believe is, or is at risk of being, a victim of sex trafficking or a severe form of trafficking in persons. ${ }^{187}$ Not later than two years after September 29, 2014, states are

18042 U.S.C $\S 675(8)$ (B)(iii)-(iv). They may reenter care until they reach the state's oldest allowable age for foster care, assuming they still meet the state's elected eligibility conditions. Id. 181 U.S. Dep'T of Health \& Human Servs. Admin. ON ChILdREN, Youth and Families, Program InSTRUCTION 5 (2010), available at http://www.acf.hhs.gov/sites/default/files/cb/pi 1011 .pdf.

182 Pub. L. No. 113-183, 128 Stat. 1919 (2014).

183 Bass, supra note 141.

184 Id.

185 Prevent Trafficking, COMMITTEE ON WAYS AND MEANS, http://waysandmeans.house.gov/ preventtrafficking/ (last visited Apr. 3, 2015).

186 Id. Some rules make it difficult for foster youth to participate in sports, sleep over at a friend's house, obtain a driver's license, get a part-time job, or engage in other age-appropriate activities.

187 Pub. L. No. 113-183, 128 Stat. 1919 (2013). This occurs in consultation with an organization experienced in dealing with at risk youth. Id. $\S 101$. 
expected to report instances of sex trafficked foster youth. ${ }^{188}$ By September 29, 2017 , this data is to be included in the adoptions and foster care analysis and reporting system (AFCRS). ${ }^{189}$ By September 29, 2018, this data must be reported to Congress and be publically available on the HHS website. ${ }^{190}$

PSTSF also requires states to develop and implement plans to expeditiously locate any child who has run away from care. ${ }^{191}$ Similarly, it directs state agencies to immediately report missing or abducted children or youth to law enforcement authorities for entry into the National Crime Information Center (NCIC) database of the Federal Bureau of Investigation (FBI) and to the National Center for Missing and Exploited Children. ${ }^{92}$ No later than two years after enactment, using the data reported under AFCARS, HHS must report to Congress on the children who run away from foster care and their risk of becoming victims of sex trafficking. ${ }^{193}$ The report must include characteristics of the children who run away and risk factors associated with children running away from care and summarize the state's efforts to provide specialized services placement options to child victims of sex trafficking. ${ }^{194}$ The report must also include efforts on behalf of the state to ensure that children in care form and maintain long-lasting connections to caring adults. ${ }^{195}$

Title II of the Act requires states to support "normalcy" 196 for foster children and extends adoption incentives. Normalcy includes implementing a "reasonable and prudent parent standard" for decisions made by foster parents or designated officials at foster care institutions. Caregivers are required to be trained in age or developmentally appropriate "reasonable and prudent parent standards." 197 The goal is to enable the caregivers to make parental decisions that "maintain the health, safety and best interest of the child" while promoting the child's participation in "extracurricular, enrichment, cultural and social activities." 198 In other words, the statute seems to be attempting to make foster care as "normal" as possible for adolescents.

Id. The text specifically states, "not later than . . . 2 years after such date of enactment." Id. The date of enactment was September 29, 2014. Id.

$\begin{array}{ll}189 & \text { Id. } \S 103 . \\ 190 & \text { Id. } \\ 191 & \text { Id. } \S 104 . \\ 192 & \text { Id. } \\ 193 & \text { Id. } \S 105 . \\ 194 & I d . \\ 195 & I d . \\ 196 & I d . \\ 197 & I d . \S 111 . \\ 198 & I d .\end{array}$


Title II of the Act also eliminates "Another Planned Permanent Living Arrangement" (APPLA) as a permanency goal for children under age $16^{199}$ and requires additional case plan and case review requirements for youth over 16 with a goal of APPLA. ${ }^{200}$ This Act also empowers foster children age 14 and older to help develop or revise their own case plans. ${ }^{201}$

These provisions are a step in the right direction toward combatting the sexual exploitation of youth in foster care. But it is not clear how the reporting directives will be enforced ${ }^{202}$ and whether state agencies and workers will have any incentive to be truthful and meticulous. Likewise, there is no statutory incentive to address and prevent actual sexual exploitation. ${ }^{203}$ Federal funding is not conditioned on receipt of the states' reports or on any other benchmarks. ${ }^{204}$

There is also no threat of withholding funding if states continue to use the APPLA goal; ${ }^{205}$ in fact, APPLA is still permitted for children over age 16 and for children under age 16 if the state agency documents "intensive, ongoing and unsuccessful efforts for family placement." ${ }^{206}$ At this point, it is hard to foresee this legislation making an immediate or substantial dent in the hundreds of thousands of youth who are currently sexually exploited, at least not without concurrent forms of accountability. It is important to note as well that the Trafficking Victims Protection Act (TVPA), ${ }^{207}$ landmark legislation

$199 I d . \S 112(\mathrm{a})(1)$. APPLA is amended by inserting "only in the case of a child who has attained 16 years of age" to section $475(5)(\mathrm{C})(\mathrm{i})$. Id.

$200 I d . \S 112(\mathrm{~b})(1)$. In order for APPLA to remain a child's permanency goal, the state agency must document intensive, ongoing, and unsuccessful efforts for family placement, including efforts to locate biological family members using search technologies (including social media). At each permanency hearing, the agency is required to ask the child about the child's desired permanency outcome and to make a judicial determination explaining why APPLA is still the best permanency plan and why it is not in the best interest of the child to be returned home, adopted, placed with a legal guardian, or placed with a fit and willing relative. At each permanency hearing, the agency is also required to specify the steps the agency is taking to ensure the reasonable and prudent parent standard is being followed and that the child has regular, ongoing opportunities to engage in age or developmentally appropriate activities.

$201 I d$. $\S 113$ ("Empowering Foster Children Age 14 and Older in the Development of Their Own Case Plan and Transition Planning for a Successful Adulthood").

202 See generally $i d$. The law requires various different reporting measures, but prescribes no enforcement provisions other than requiring that the HHS report to Congress the numbers reported.

203 Id. The law simply requires states to report instances of sex trafficking to both the law enforcement authorities and the AFCARS and to respond and locate children who have run away from foster care.

204 Id. $\S 102$.

$205 I d . \S 475 \mathrm{~A}$.

$206 I d$.

207 Pub. L. No. 106-386, 114 Stat. 1464 (2000). 
passed in $2000^{208}$ and reauthorized with amendments in 2003, 2005, 2008, and 2013, has provisions specifically targeted to addressing the problem of domestic sexual exploitation of minors, ${ }^{209}$ and the problem has only gotten worse since 2013. ${ }^{210}$ Other federal laws have also had little effect. ${ }^{211}$

208 Current Federal Laws, POLARIS, http://www.polarisproject.org/what-we-do/policyadvocacy/national-policy/current-federal-laws (last visited Apr. 11, 2015) ("The Trafficking Victims Protection Act of 2000 (TVPA) is the cornerstone of federal human trafficking legislation, and established several methods of prosecuting traffickers, preventing human trafficking, and protecting victims and survivors of trafficking. The act establishes human trafficking and related offenses as federal crimes, and attaches severe penalties to them. It also mandates restitution be paid to victims of human trafficking. It further works to prevent trafficking by establishing the Office to Monitor and Combat Trafficking in Persons, which is required to publish a Trafficking In Persons (TIP) report each year.").

209 See, e.g., Summary of the Trafficking Victims Protection Act (TVPA) and Reauthorizations, ALLIANCE TO END SLAVERY AND TRAFFICKING, http://endslaveryandtrafficking.org/fy2014/ Relevant-Authorization-Statutes.php (last visited Apr. 11, 2015). TVPA recognized that modernday slavery takes place in the context of fraud and coercion, as well as force, and defines "a commercial sex act [as one that] is induced by force, fraud, or coercion, or in which the person induced to perform such an act has not attained 18 years of age." 22 U.S.C. $\S 7102(9)(A)(2013)$.

The TVPA seeks to combat trafficking by promoting a policy of "3 Ps": prosecution, protection, and prevention: Prosecution involves passing the appropriate laws that criminalize trafficking, and jailing the abusers who exploit other humans for profit. Protection involves identifying victims, providing them with medical care and shelter (and if necessary witness protection), and, when appropriate, repatriating them. Prevention involves raising awareness of the inhumane practices involved in the trafficking trade and promoting a paradigm shift that seeks to reduce the demand for the "fruits" of human trafficking.

Trafficking Victims Protection Act, FIGHT SLAVERY Now!, http://fightslaverynow.org/why-fightthere-are-27-million-reasons/the-law-and-trafficking/trafficking-victims-protection-act/traffic king-victims-protection-act/ (last visited Apr. 11, 2015).

210 U.S. DEP'T OF JUSTICE, supra note 70, at 33.

211 See 18 U.S.C. $\S 1591$ (2013) ("Sex Trafficking of Children or by Force, Fraud, or Coercion"). Section 1591 criminalizes sex trafficking, which is defined as causing a "person to engage in a commercial sex act" under certain statutorily enumerated conditions. Id. §1591(a). A "'commercial sex act' means any sex act, on account of which anything of value is given to or received by any person." Id. $\S 1591(\mathrm{e})(3)$. The specific conditions are the use of force, fraud, or coercion, or conduct involving persons under the age of 18 . Id. $\S 1591(\mathrm{a})$. The punishment for conduct that either involves a victim who is under the age of 14 or involves force, fraud, or coercion is any term of years or life. Id. $\S 1591(\mathrm{~b})(1)$. The punishment for conduct that involves a victim between the ages of 14 and 18 is not to be less than ten years. Id. $§ 1591(\mathrm{~b})(2)$. 


\section{v. Constitutional Rights}

\section{A. The Foster Child's Right To Be Free from Harm While in Custody}

\section{Case Law Regarding Foster Children}

Foster children's rights while in custody of the state are not well settled. However, recent federal decisions indicate that, under the Substantive Due Process Clause of the Fourteenth Amendment, foster children have a right to be free from harm while in custody; agencies can be held liable for deprivation of this right. According to the Supreme Court, states deprive individuals of their substantive due process when they are deliberately indifferent to their fundamental rights. ${ }^{212}$ "Deliberate indifference" is defined as conscious or "reckless disregard" by a state actor. ${ }^{213}$ In the last two decades, courts have occasionally found state foster care agencies to have been deliberately indifferent to the substantive due process rights of foster children.

Until the early 1990s, there was no judicial precedent at all for a foster child's due process right to be free from harm. ${ }^{214}$ In LaShawn A. v. Dixon, ${ }^{215}$ the court recognized that children have a right to reasonably safe placements where they will not suffer physical or emotional harm. ${ }^{216}$ The court held that the Baltimore City Department of Social Services (DSS) ${ }^{217}$ had a "special relationship" with the city's foster care children. ${ }^{218}$ However, the court did not say what this special relationship entailed. Should the state's action be judged on a "professional judgment" 219 standard, meaning the plaintiff has to prove only negligence by the state, or must the state's actions rise to the level of

\footnotetext{
212 See Sacramento v. Lewis, 523 U.S. 833, 850 (1998); Farmer v. Brennan, 511 U.S. 825, 828 (1994).
}

213 See Farmer, 511 U.S. at 839 (describing deliberate indifference in the context of a prison official: "A prison official may be held liable under the Eighth Amendment for acting with 'deliberate indifference' to inmate health or safety only if he knows that inmates face a substantial risk of serious harm and disregards that risk by failing to take reasonable measures to abate it.").

214 See Michael B. Mushlin, Unsafe Havens: The Case for Constitutional Protection of Foster Children from Abuse and Neglect, 23 HARV. C.R.-C.L. L. REV. 199 (1988).

215762 F. Supp. 959 (D.D.C. 1991), aff'd and remanded sub nom. LaShawn A. ex rel. Moore v. Kelly, 990 F.2d 1319 (D.C. Cir. 1993).

$216 \quad$ Id. at 992.

217 Hereinafter, all Departments of Social Services that are defendants in cases will be referred to as "DSS" or "the state."

218 LaShawn, 762 F. Supp. at 992 n.27.

219 The "professional judgment" standard was first articulated in Youngberg v. Romeo, 457 U.S. 307 (1982). The professional judgment standard is discussed, infra, in text accompanying notes $232-35$. 
"deliberate indifference" or "shock the conscience" 220 in order to find a constitutional violation?

Following the LaShawn ${ }^{221}$ decision, the right to be free from harm has been precarious and often denied. In White by White $v$. Chambliss, ${ }^{222}$ the mother filed a $\S 1983$ suit $^{223}$ against South Carolina DSS after her daughter died in a foster home placement because of injuries (a blow to the head) sustained from the abusive foster parents. ${ }^{224}$ The mother claimed a violation of her daughter's substantive due process rights under the Fourteenth Amendment. ${ }^{225}$ The court held that negligence was not enough to prove such a violation; the daughter's death did not "result from the DSS defendants' violation of any "clearly established statutory or constitutional rights of which a reasonable person would have known.",226 DSS's actions did not amount to deliberate indifference because it was not "on notice of a danger and chose to ignore the danger notwithstanding the notice." 227 Therefore, DSS was entitled to qualified immunity. ${ }^{228}$

In Conn v. Bull, ${ }^{229}$ a two-year-old foster child drowned in the foster mother's pool and the county was sued under a deliberate indifference

220 The Supreme Court has established three levels of fault for state action-negligence, deliberate indifference, and conduct that shocks the conscience. Sacramento v. Lewis, 523 U.S. $833,849,851,856$ (1998). "Liability for negligently inflicted harm is categorically beneath the threshold of constitutional due process," $i d$. at 849 ; "Deliberate indifference" is the standard to employ "when actual deliberation [by a state actor] is practical," $i d$. at 851; and the highest standard to apply is the "shocks-the-conscience" test, $i d$. at 856.

221762 F. Supp. 959 (D.D.C. 1991), aff'd and remanded sub nom. LaShawn A. ex rel. Moore v. Kelly, 990 F.2d 1319 (D.C. Cir. 1993).

222112 F.3d 731 (4th Cir. 1997).

223 To state a claim under $\S 1983$, a plaintiff must allege a person acting under color of state law engaged in conduct that violated a right protected by the Constitution or laws of the United States. 42 U.S.C. \$ 1983 (2013); see also Sacramento v. Lewis, 523 U.S. at 841. In the rest of the cases described in this Section, the plaintiffs made $\S 1983$ claims that their substantive due process rights under the Fourteenth Amendment were denied. Herein, all constitutional claims described, unless otherwise indicated, were made by private citizens under $\S 1983$ for violation of substantive due process under the Fourteenth Amendment.

224 White, 112 F.3d at 734 .

225 Id

226 Id. (quoting Harlow v. Fitzgerald, 457 U.S. 800, 818 (1982)).

227 Id. at 737.

228 Id. at 740 . Qualified immunity protects government officials from individual liability under $\S 1983$ for actions taken while performing discretionary functions, unless their conduct violates clearly established statutory or constitutional rights of which a reasonable person would have known. Thus, before liability will attach, the contours of the right must be sufficiently clear that a reasonable official would understand that what he is doing violates that right.

229307 F. App'x 631 (3d Cir. 2009). 
theory. ${ }^{230}$ The court held that there was no evidence that the parties were deliberately indifferent ${ }^{231}$ or that the individual officials were "responsible for assuring the safety of the home, evaluating [the foster mother's] fitness as a parent, or placing [the child] in foster care." ${ }^{, 232}$ At best, the facts, as alleged, established negligence, but they were not enough to satisfy the deliberate indifference standard. ${ }^{233}$ Other cases have also held strictly to the deliberate indifference standard, even when children have died in foster care. ${ }^{234}$

Only recently have plaintiffs had success, but only on the deliberate indifference standard and only when the defendants had actual knowledge of the harm. In H.A.L. v. Foltz, ${ }^{235}$ Florida DSS was held liable for sexual abuse in the foster home because "no reasonable person in [the] [d]efendants' place could have believed that, by doing nothing to protect the children, they could carry out their duties consistently with the Constitution."236 According to the court, the defendants actually knew about the substantial risk of harm in the Shick home and nevertheless acted with deliberate indifference. ${ }^{237}$ Other cases have held likewise. ${ }^{238}$ As the Doe ex rel. Johnson v. South Carolina Department of Social Services ${ }^{239}$ court noted, in a claim regarding violations of due process during a child's adoption, the state has "some responsibility for

$\begin{array}{ll}230 & \text { Id. } \\ 231 & \text { Id. at } 634 . \\ 232 & \text { Id. } \\ 233 & \text { Id. at } 635 . \\ 234 & \text { See Lethbridge ex rel. Estate of Lethbridge v. Forrest, No. 08-11423, 2010 WL 1417778, at }\end{array}$ *68 (E.D. Mich. Apr. 5, 2010) (finding state not deliberately indifferent when plaintiff's son died in foster care after severe abuse by foster parents); Olivia Y. ex rel. Johnson v. Barbour, $351 \mathrm{~F}$. Supp. 2d 543, 553-56 (S.D. Miss. 2004) (finding no violation of foster children's substantive due process rights even though there was a special relationship between the state with those children; it would be inappropriate to hold caretakers liable for constitutional deprivations when those caretakers had exercised their professional judgment in determining the best course of conduct).

$235 \quad 551$ F.3d 1227 (11th Cir. 2008).

236 Id. at 1231.

237 Id. at 1232 ("Taken together, these factors show that Defendants actually knew, and were deliberately indifferent to, the substantial risk of Plaintiffs being sexually abused in the Shick home.").

238 E.g., Estate of Smith v. Hamilton Cnty. Dep't of Job \& Family Servs., No. 1:06cv362, 2007 WL 2572184, at *9 (S.D. Ohio Aug. 31, 2007); see also A.P. ex rel. Bazerman v. Feaver, 293 F. App'x 635, 653, 674 (11 th Cir. 2008) (dismissing claims against individual defendants because "our task ... is to determine what each defendant actually knew prior to the alleged abuse and what actions he or she took in response to that knowledge. . . The complaint alleges many facts from which the defendants could, or perhaps should, have inferred that a substantial risk of serious harm existed in the Calhoun home; however, there are no specific allegations that they actually drew such an inference and then chose to disregard it.").

239597 F.3d 163 (4th Cir. 2010). 
[the child's] safety and general well-being."240 But that certainly does not "mean that every child in foster care may prevail in a $\S 1983$ action against state officials." 241

Only one court has held that the professional judgment standard is appropriate, ${ }^{242}$ but it was never actually applied since the case, a class action, ended in a consent decree. According to the Kenny A. ex rel. Winn v. Perdue ${ }^{243}$ court, state officials act in place of parents for foster children, who have done nothing wrong. ${ }^{244}$ Therefore, "foster children are entitled to a high standard. Something more than refraining from indifferent action is required to protect these innocents." 245 Unfortunately, "something more" was not clearly defined or applied to specific plaintiffs, and this case was not reported. ${ }^{246}$ On the bright side, the consent decree forced the state to achieve and sustain some 31 outcomes in order to address constitutional concerns over foster care placements. $^{247}$

The Kenny $A$. court actually followed the constitutional standard that should be applied to foster children based on the Supreme Court's other Fourteenth Amendment due process jurisprudence. The Supreme Court has recognized the substantive due process rights of other analogous, and less sympathetic, populations. According to the Supreme Court, prisoners, ${ }^{248}$ the

240 Id. at 175 (citing DeShaney ex rel. DeShaney v. Winnebago Cnty. Dep't Soc. Servs., 489 U.S. $189,200(1989))$.

241 Id.

242 Kenny A. ex rel. Winn v. Perdue, No. 1:02-cv-1686-MHS, 2004 WL 5503780, at *3 (N.D. Ga. Dec. 13, 2004).

243 Id.

244 Id. ("The compelling appeal of the argument for the professional judgment standard is that foster children, like involuntarily committed patients, are "entitled to more considerate treatment and conditions' than criminals. These are young children, taken by the state from their parents for reasons that generally are not the fault of the children themselves. The officials who place the children are acting in place of the parents." (quoting LaShawn A. v. Dixon, 762 F. Supp. 959, 996 (D.D.C. 1991))).

245 Id. at *4 (quoting Braam ex rel. Braam v. State, 81 P.3d 851, 859 (Wash. 2003)).

246 The court applied the professional judgment standard in deciding that there were genuine issues of material fact for trial, but the issues were never adjudicated for more clarity on what or how social services should apply professional judgment. The court only found that the state departed from minimal professional standards by failing to (1) adequately investigate and respond to allegations of abuse, (2) ensure reasonable caseloads for caseworkers, (3) ensure that caseworkers regularly visit foster children to monitor their safety, (4) provide consistent casework services, (5) maintain accurate and timely casework documentation, and (6) adequately screen and approve foster homes. Id. at *4.

247 The Kenny A. vs. Sonny Perdue Consent Decree, GA. Dep'T of Human Servs., https://dfcs. dhs.georgia.gov/kenny-vs-sonny-perdue-consent-decree (last visted Mar. 1, 2015).

248 Rhodes v. Chapman, 452 U.S. 337 (1981); Bell v. Wolfish, 441 U.S. 520 (1979). 
mentally ill and disabled, ${ }^{249}$ residents of state juvenile training schools, ${ }^{250}$ suspects in police custody, ${ }^{251}$ and pretrial detainees ${ }^{252}$ all have constitutional rights while in custody. Importantly, adult mental institutions are held to higher standards than prisons. In Youngberg $v$. Romero, ${ }^{253}$ the Court rejected the deliberate indifference standard because the right to safety for the institutionalized was an "unquestioned duty",254 of the state and was one of the "essentials of the care that the state must provide." 255 Because the mentally disabled, unlike convicts, have not been found guilty of any wrongdoing, government officials cannot make decisions that constitute a substantial departure from "professional judgment," causing injury to these liberty interests. ${ }^{256}$ The Court rejected the state's argument that the Eighth Amendment subjective deliberate indifference or criminal recklessness standard should govern the due process rights of those who are civilly, as opposed to criminally, committed in state institutions. ${ }^{257}$

Why then, when courts hold state foster care agencies accountable, will they do so only on the deliberate indifference standard? Foster children are even more defenseless and sympathetic than involuntarily committed adults. They are innocent children, the mere subjects (for better or worse) of the state's actions against their parents, not them. ${ }^{258}$ When a child is placed in foster care, the state assumes the role of parent to a most vulnerable population. As one federal court acknowledged, "[b]y "finding the children and placing them with state approved families ... , the state assumes an important continuing, if not immediate, responsibility for the child's wellbeing." 259 Biological parents have their children taken away every day in this country for actions which fall far below the "deliberate indifference" standard; 260 surely state parents should be required to make professional judgments about their children.

\footnotetext{
249 Youngberg v. Romeo, 457 U.S. 307 (1982).

250 Santana v. Collazo, 533 F. Supp. 966 (D.P.R. 1982), modified, 714 F.2d 1172 (lst Cir. 1983).

251 City of Revere v. Mass. Gen. Hosp., 463 U.S. 239, 245 (1983).

252 Bell, 441 U.S. at 531 (The confinement of pretrial detainees indiscriminately with convicted persons is unconstitutional unless such a practice is "reasonably related to the institution's interest in maintaining jail security.").

253 Youngberg, 457 U.S. 307.

254 Id. at 324.

$255 I d$.

$256 \quad$ Id. at 323.

257 Id. at 325

258 As demonstrated throughout this Article, state actions are often biased and subjective.

259 Morrow v. Balaski, 719 F.3d 160, 173 (3d Cir. 2013) (quoting D.R. ex rel. L.R. v. Middle Bucks Area Vocational Technical Sch., 972 F.2d 1364, 1372 (3d Cir. 1992)).

260 See generally Martin Guggenheim, How Children's Lawyers Serve State Interests, 6 NEV. L.J. 805 (2006) (In "the large majority of cases . . children are ordered into foster care even
} 


\section{Case Law Regarding Analogous Populations}

\section{i. Pretrial Detainees and Prisoners}

Pretrial detainees and prisoners have a constitutional right to be protected from state actions, or lack thereof, which lead to their suicide. ${ }^{261}$ In order to prevail in a $\S 1983$ claim, the plaintiff must prove deliberate indifference on the part of the state. However, deliberate indifference can be demonstrated when prison officials should know about a suicide risk and fail to take reasonable or professional steps to prevent the suicide. ${ }^{262}$ In Estate of Miller ex rel. Bertram v. Tobiasz, ${ }^{263}$ the court held that the intake nurse, psychology associate, and prison guards were all subjectively aware that an inmate was a suicide risk. The prison officials did not need actual knowledge; they "either knowingly or recklessly disregarded it."264 Once the subjective knowledge risk is established, they are accountable for taking "reasonable steps" to prevent the harm from the inmate's suicidal tendencies. ${ }^{265}$

Likewise, in Comstock v. McCrary, ${ }^{266}$ the court held that evidence was sufficient to establish liability for a prison psychologist who wrote a "grossly

though they have not suffered, and there is no serious risk of suffering, serious harm," and thousands of cases arise against parents in which mere neglect, based on flimsy evidence, is alleged.); see also O’Donnell v. Brown, 335 F. Supp. 2d 787 (W.D. Mich. 2004); Anita Hassan, Mixed Reviews After CPS Takes Kids from Family Shed, Hous. CHRON. (July 8, 2011), http://www.chroncom/news/houston-texas/article/Mixed-reviews-after-CPS-takes-kids-fromfamily-2080318.php; Alan Farnham, Answer to Recession: Houston Family of Eight Living in Self-Storage, ABC NEWS (July 6, 2011), http://abcnews.go.com/Business/houston-texas-familyliving-storage-shed/story?id $=14009261$.

261 For pretrial detainees, the Fourteenth Amendment is implicated; for prisoners, it is the Eighth Amendment, but the standard is the same. See Payne for Hicks v. Churchich, 161 F.3d 1030, 1041 (7th Cir. 1998) (citing Antonelli v. Sheahan, 81 F.3d 1422, 1428 (7th Cir. 1996)) ("We have applied the deliberate indifference standard to a pretrial detainee's $\S 1983$ claim."). When the $\S 1983$ claim is based on a jail suicide, the degree of protection accorded a detainee is the same that an inmate receives when raising an inadequate medical attention claim under the Eighth Amendment-deliberate indifference. See Mathis v. Fairman, 120 F.3d 88, 91 (7th Cir. 1997) ("A prison official violates the Eighth Amendment (which applies to persons who have been convicted) and the due process clause of the Fourteenth Amendment (which applies to pretrial detainees ...) when he is deliberately indifferent to a substantial risk of serious harm to an inmate."); see also Estate of Cole v. Fromm, 94 F.3d 254, 259 n.1 (7th Cir. 1996); Hall v. Ryan, 957 F.2d 402, 405-06 (7th Cir. 1992). Eighth Amendment rights for prisoners are also implicated in suicide cases, but will not be discussed here as foster children do not have Eighth Amendment rights. See, e.g., Estate of Novack v. Cnty. of Wood, 226 F.3d 525 (7th Cir. 2000); Estate of Cills v. Kaftan, 105 F. Supp. 2d 391 (D.N.J. 2000).

262 See generally Estate of Miller ex rel. Bertram v. Tobiasz, 680 F.3d 984 (7th Cir. 2012).

263 Id. at 989.

264 Id. (emphasis added).

265 Id. at 990.

266 Comstock v. McCray, 273 F.3d 693 (6th Cir. 2001). 
inadequate" psychological evaluation of a suicidal detainee. ${ }^{267}$ "In this case, the plaintiff has alleged facts which show that McCrary released Montgomery from suicide watch without making any 'reasoned assessment... of the patient's suicide risk." "268 The evaluation was conducted with "none of [the psychologist's] professional skills." ${ }^{269}$ Therefore, he was constitutionally responsible for his suicide.

In Sanville v. McCaughtry, ${ }^{270}$ an inmate, who had attempted suicide in the past and whose mother had warned the prison of his tendencies, wrote a last will and testament and refused to eat while in his cell. The guards were therefore liable when he covered his cell windows with toilet paper, fashioned a noose from his sheets, and asphyxiated himself. ${ }^{271}$ According to the court, "it seems quite possible that ... the guards could have been aware of the risk that Matt would commit suicide,"272 yet they failed to take "reasonable steps to prevent" it. ${ }^{273}$ The prison guards were accountable for reckless disregard-not actual knowledge - and for their lack of reasonable action. ${ }^{274}$

The language in these prison suicide cases resembles the language of a professional judgment standard. ${ }^{275}$ Even when ostensibly applying the term "deliberate indifference," the courts look to the totality of circumstances to determine whether due process was deprived. ${ }^{276}$ The courts find enough evidence when state officials fail to be reasonable. ${ }^{277}$ This line of cases is helpful for making an argument for liability for foster runaways. In runaway and missing foster child cases, a confluence of factors contribute to their absence from care and the harms that ensue.

\section{ii. Involuntarily Committed Adults}

Involuntarily committed adults in mental institutions who harm themselves because they are unsupervised are also protected under the Fourteenth Amendment. The professional judgment standard has been applied.

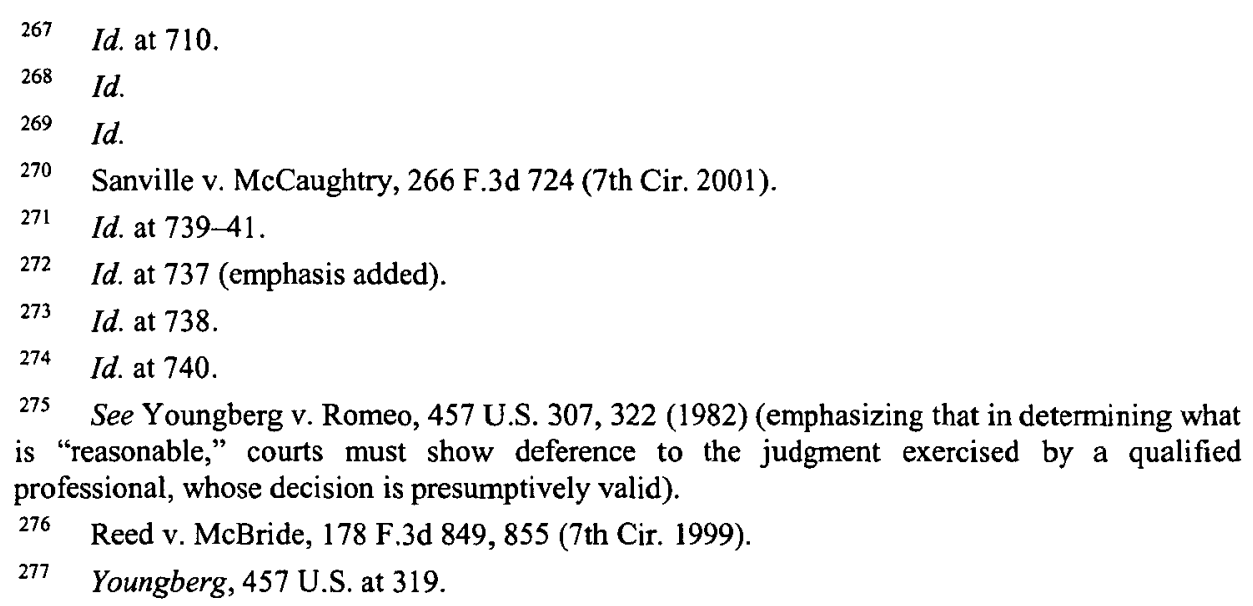


In Gann v. Schramm ${ }^{278}$ Gann escaped from the ward by picking the lock on the screen to his window. ${ }^{279} \mathrm{He}$ was apprehended by a state policeman after a 15 minute absence. ${ }^{280}$ Upon his return, he was strip searched for contraband and then examined by another staff doctor who ordered a sleeping pill for him. ${ }^{281}$ The next morning, doctors came to see Gann while on their morning rounds. He was still asleep and they decided not to wake him but continued "close observation." ${ }^{282}$ After a roll call that same evening, Gann was reported missing again. A search of the ward was instituted and Gann was not found. ${ }^{283}$ The next morning, Gann was found dead in the closet of his room in the Admissions Ward ${ }^{284} \mathrm{~A}$ plastic bag like the type used in the facility's kitchen was found over his head. ${ }^{285}$ The court held that the employees could be constitutionally liable for this series of events under a professional judgment standard. ${ }^{286}$ The court held, quoting Youngberg, that "liability may be imposed only when the decision by the professional is such a substantial departure from accepted professional judgment, practice, or standards as to demonstrate that the person responsible actually did not base the decision on such a judgment."287

Schorr v. Borough of Lemoyne ${ }^{288}$ also involved a patient running away from involuntary commitment. The parents of a son who was diagnosed with bipolar disorder brought a $\S 1983$ suit for the death of the son after he eloped from the hospital. ${ }^{289}$ The court held that even though it was a private hospital, it was "clothed" with the authority of state law through its contract with the state, among other things ${ }^{290}$ and it acted under color of state law for purposes of the $\S 1983$ claim. ${ }^{291}$ The Fourteenth Amendment protected Schorr's due process rights to be free from harm when involuntarily committed, including during the period he had run away, and therefore the suit was allowed to go forward. ${ }^{292}$

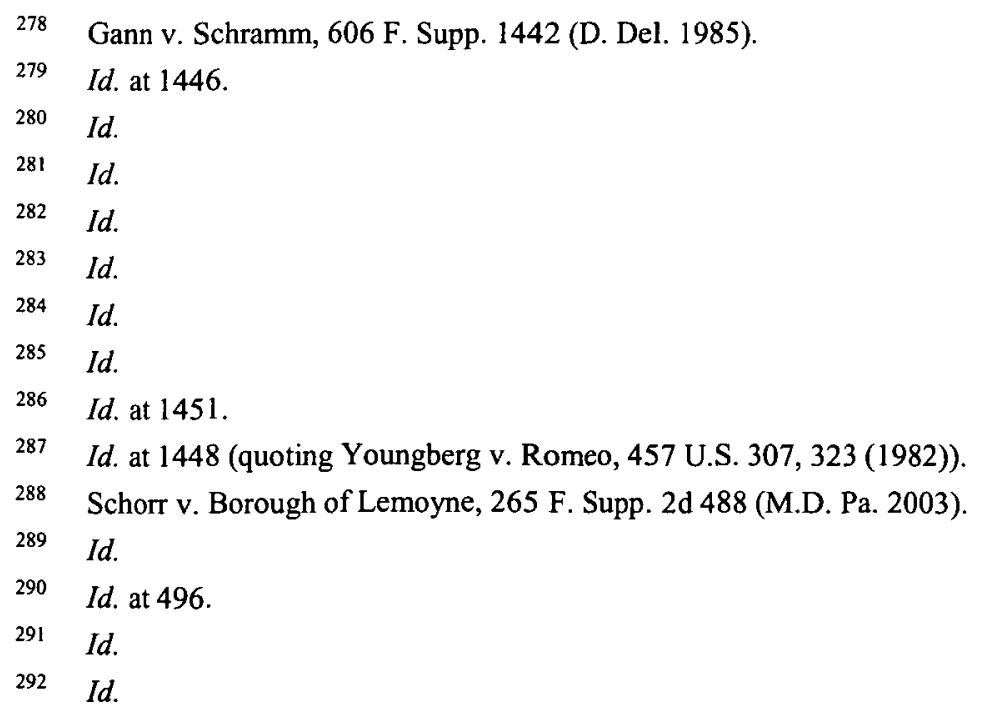




\section{iii. Nursing Home Residents}

An analogy can also be made to nursing home elopement and wandering cases. About $10 \%$ of all lawsuits involving nursing homes deal with elopements, or wandering. ${ }^{293}$ Nursing homes are required by law to provide adequate supervision to prevent wandering and the related complications and injuries. ${ }^{294}$ Nursing homes regulated by federal law can now also be liable for deprivation of the due process rights of their voluntary residents. In Grammer v. John J. Kane Regional Centers, ${ }^{295}$ the Third Circuit allowed a $\S 1983$ claim to go forward against a nursing home whose failure to provide proper care and supervision resulted in the death of a resident from malnourishment and pressure sores.

If all of these populations-prisoners, mentally disabled adults, and the elderly-have some form of constitutional right to be free from harms that result from improper care and lack of supervision, surely the most vulnerable and powerless population in the custody of the state should be entitled to the same. Child wards of the state are, by definition, held involuntarily and in need of deliberate, meaningful decision making by their guardians. They are not legally permitted to run away or be missing. Their guardians are the ones responsible for losing them. In fact, under age 18, they are not legally able to make any of their own decisions. Surely these young people should not be responsible for ensuring their own constitutional rights.

\section{B. The Foster Child's Right To Be Free from Harm When Missing}

There have been a handful of Fourteenth Amendment cases regarding runaway and missing foster children, with varying results and no precedent. ${ }^{296}$ Several cases simply follow the deliberate indifference standard. In Smith $v$. District of Columbia, ${ }^{297}$ a 17 -year-old was living in an apartment as part of an independent living program. ${ }^{298}$ There was little oversight and procedure for selecting these companies or the management of the programs. ${ }^{299}$ There were also problems with the staff itself, including a counselor buying marijuana for

\footnotetext{
293 Residents of Nursing Homes Receiving Medicaid Can Now Bring Civil Rights Claims Challenging Quality of Treatment, FOX ROTHSCHILD (July 2009), http://www.foxrothschild.com/ newspubs/newspubsArticle.aspx?id=10650.

29442 U.S.C. $\S 1396(r)(1)-(8)(2013)$.

295 Grammer v. John J. Kane Reg'l Ctrs.-Glen Hazel, 570 F.3d 520 (3d Cir. 2009).

296 See generally Smith v. Dist. of Columbia, 413 F.3d 86 (D.C. Cir. 2005); Nicini v. Morra, 212 F.3d 798 (3d Cir. 2000); Tate v. Arbor Heights Cmty. Justice Ctr., No. 06-14877, 2008 WL 3318733 (E.D. Mich. Aug. 8, 2008).

297 Smith, 413 F.3d 86.

298 Id. at 89

$299 \quad I d$
} 
the children. ${ }^{300}$ DSS did little, if anything, to monitor the facility. ${ }^{301}$ In violation of curfew, the plaintiff and his roommate let a visitor into their apartment who shot and killed them. The murders brought the death toll of youths living in the facility "to three out of sixteen (a fourth would be murdered by the end of the year). ${ }^{302}$ The court held that by not adopting any criteria for independent living programs and falling "below what national standards of care require of states," DSS was deliberately indifferent to the victim's welfare. ${ }^{303}$

Nicini v. Morra ${ }^{304}$ also used the deliberate indifference standard. Plaintiff was 15 years old when he went to the hospital after an attempted suicide, and told caseworkers that his father physically abused him. ${ }^{305}$ Plaintiff was placed in two foster homes but ran away; he was subsequently sent by DSS to live with the Morra family. ${ }^{306} \mathrm{He}$ ran away from the Morras and then from the hospital to which he was admitted for psychiatric evaluation. He ran back to the Morras and it was eventually arranged that the plaintiff would be placed back in their home. ${ }^{307}$ Caseworkers checked the home and said that everything was positive, and there were no records of sexual abuse when the caseworker performed background checks on the family. ${ }^{308}$ The state and courts understood the plaintiff's placement as an unofficial home, not a foster home. ${ }^{309}$ The plaintiff later ran away again from the Morras' home, and 'told investigators that since the second or third day of his arrival there, Edward Morra [the uncle] had been providing him with drugs and alcohol and assaulting him sexually."310 It was later discovered that the uncle had prior convictions of "corrupting the morals of a minor and for distribution of controlled substances to minors" and was found guilty for his actions with the plaintiff. ${ }^{311}$ In the child's $\S 1983$ suit against DSS, the court held that even though the Morras were not a foster home, the plaintiff was in state custody and the state placed the plaintiff in the Morra home over the objections of his parents and aunt, so the placement was a

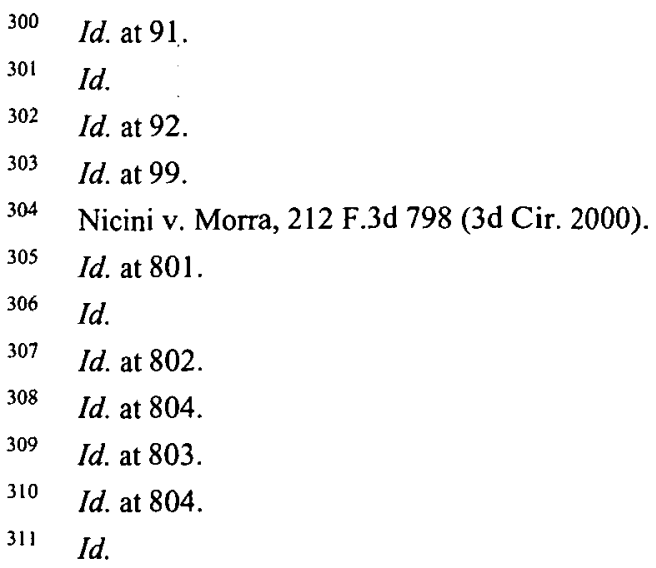


"special relationship." ${ }^{312}$ However, the court held that the caseworker's conduct did not rise to deliberate indifference and amounted to negligence, at worst. ${ }^{313}$

A district court case, Tate v. Arbor Heights Community Justice Center, ${ }^{314}$ hinted at a standard higher than deliberate indifference, but still did not establish a clear constitutional right for runaways. ${ }^{315}$ Tate had a pattern of running away from home and was involuntarily committed to a low-security juvenile facility operated by DSS. ${ }^{316}$ While under the supervision of two staff members, Tate ran away with some young adult males, and at some point while away from the center, Tate claims she was raped. ${ }^{317}$ Tate alleged the staff violated her Fourteenth Amendment rights by allowing her out of sight and failing to prevent her from running away. ${ }^{318}$ The court stated, "the Fourteenth Amendment imposes on the state 'an unquestioned duty to provide reasonable safety for all residents and personnel within the institution," 319 and found that the staff knew Tate displayed a compulsion toward risky sexual behavior (running away before with young adult males), a diminished capacity for selfcontrol, and a known propensity for truancy. ${ }^{320}$ Her status as a state ward was predicated on the judgment that she required supervision to avoid endangering

\footnotetext{
$312 \quad I d$. at 809.

313 Id. at 815.

314 Tate v. Arbor Heights Cmty. Justice Ctr., No. 06-14877, 2008 WL 3318733 (E.D. Mich. Aug. 8, 2008).
}

315 "Throughout this analysis, courts must acknowledge that a heightened degree of protection must be afforded to the involuntarily committed." Id. at *4 (quoting Terrance v. Northville Reg'l Psychiatric Hosp., 286 F.3d 834, 849 (6th Cir. 2002)).

$\begin{array}{ll}316 & \text { Id. at *1. } \\ 317 & \text { Id. at *2. }\end{array}$

318 Tate claimed that Larson and Lenoir violated her Eighth and Fourteenth Amendment rights by failing to do more to prevent her from running away at the movie theater. Because Tate was involuntarily committed to Arbor Heights rather than being convicted in criminal proceedings, she was not subjected to "punishment" within the meaning of the Eighth Amendment; the Fourteenth Amendment supplies the proper constitutional standard for evaluating her claim. $I d$. at *3 (citing Youngberg v. Romeo, 457 U.S. 307, 314-16 (1982)) (recognizing involuntarily committed patient's right to "conditions of reasonable care and safety" under the Fourteenth Amendment); Terrance, 286 F.3d at 848 ("The involuntarily committed have greater rights regarding confinement under the Fourteenth Amendment than criminals are due under the Eighth Amendment."); Gann v. Schramm, 606 F. Supp. 1442, 1447-49 (D. Del. 1985) (recognizing Fourteenth Amendment substantive due process claim under $\S 1983$ for suicide death of involuntarily committed mental patient).

319 Tate, 2008 WL 3318733, at *4 (quoting Youngberg, 457 U.S. at 342).

320 The court found that her impulsivity and unrestrained sexuality resulted in a serious danger to herself that may be likened to a suicidal impulse. As such, the court found it compelling that other courts have found that summary judgment is inappropriate where hospital staff disregard a serious risk of suicide. See, e.g., Sidwell v. Cnty. of Jersey, No. 05-cv-530-DRH, 2006 WL 1375224 (S.D. Ill. May 15, 2006). 
her own health and safety. ${ }^{321}$ Thus, the staff should have foreseen the substantial risk, and therefore, their motion for summary judgment was denied. ${ }^{322}$

Ward ex rel. Bazerman v. Feaver ${ }^{323}$ went further in establishing liability, but still fell short of declaring a constitutional right for runaways and missing foster children. Foster child Valerie Ward was raped while missing from her foster home. ${ }^{324}$ The court found that the state could be held responsible for the crime committed against Valerie because she had a tendency to run away, which the state was aware of; she was not properly supervised or cared for in her foster home; and she was placed in a foster home rife with problems, thereby exposing her to danger and harm. ${ }^{325}$ The court stated,

children in foster homes, unlike children in public schools, are isolated; no persons outside the home setting are present to witness and report mistreatment. The children are helpless. Without the investigation, supervision, and constant contact required by statute, a child placed in a foster home is at the mercy of the foster parents. ${ }^{326}$

The Ward court drew on other cases to show where it would draw the line in terms of state responsibility for a child in custody. In Zemola $v$. Johnson, ${ }^{327}$ plaintiff Elizabeth Zemola was placed in a group home known to be loosely structured and dangerous, even though the state was aware of Zemola's suicidal tendencies, lack of self-control, and violent background, and it believed she should be placed in a highly structured environment with close psychiatric monitoring. ${ }^{328}$ While in the group home she was introduced to pimps, used as a prostitute for child pornography, and given drugs. ${ }^{329}$ The court found that placing Zemola in such a "snake pit" constituted a violation of her constitutional rights. ${ }^{330}$ Moreover, the court found no qualified immunity would apply because it was "self-evident that by placing Zemola in an environment

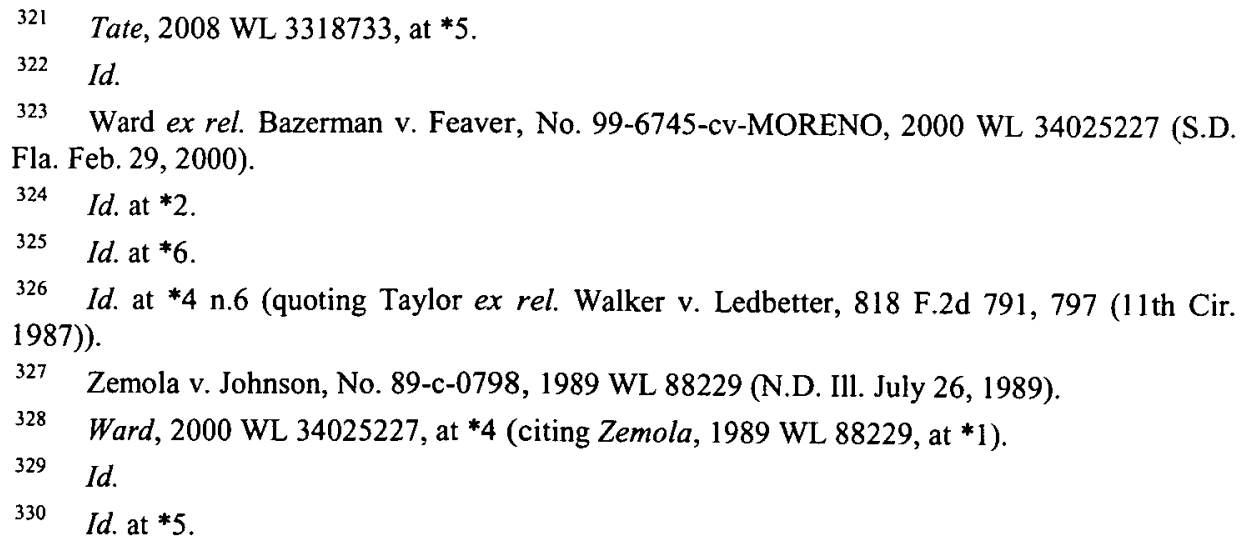


where she would be expected to be abused by outsiders" her constitutional rights were violated. ${ }^{331}$ In contrast, in Cooper v. Montgomery County Office of Children \& Youth, ${ }^{332}$ the district court granted the state's motion to dismiss because the causal link between what happened to the foster child when physically outside of the foster home-he was struck by a truck and killed while crossing the street-was too remote. ${ }^{333}$

In the Ward case, while the defendants tried to argue that Valerie was not harmed by the foster parent or on foster home premises, the court made a distinction, saying that Valerie's psychological problems and tendency to run away reinforced the state's affirmative duty to the child. ${ }^{334}$ Valerie's actual location at the time of the injury did not take away from the duties owed by the state given the circumstances. ${ }^{335}$ The court dismissed the state's motion to dismiss $^{336}$ and denied qualified immunity. ${ }^{337}$

One wrongful death case also provides guidance because it involved a crime committed against a runaway who was not a foster child at the time of the murder but was receiving child welfare services at home. In Tobias $v$. County of Racine, ${ }^{338}$ the adolescent was in foster care and had a history of running away from home and subsequently from foster home placements. ${ }^{339}$ The teenager was returned to her mother, but the mother signed a voluntary agreement to continue services with social services. ${ }^{340}$ Four months later, the teenager ran away again to a dangerous part of the county. ${ }^{341}$ After this incident, the caseworker went to the apartment and concluded that it was safe and left her there as long as she agreed to go to counseling. ${ }^{342} \mathrm{~A}$ few days later, the teenager was shot and killed near the apartment. ${ }^{343}$ The teenager's mother brought a wrongful death action against the county for negligence "when it

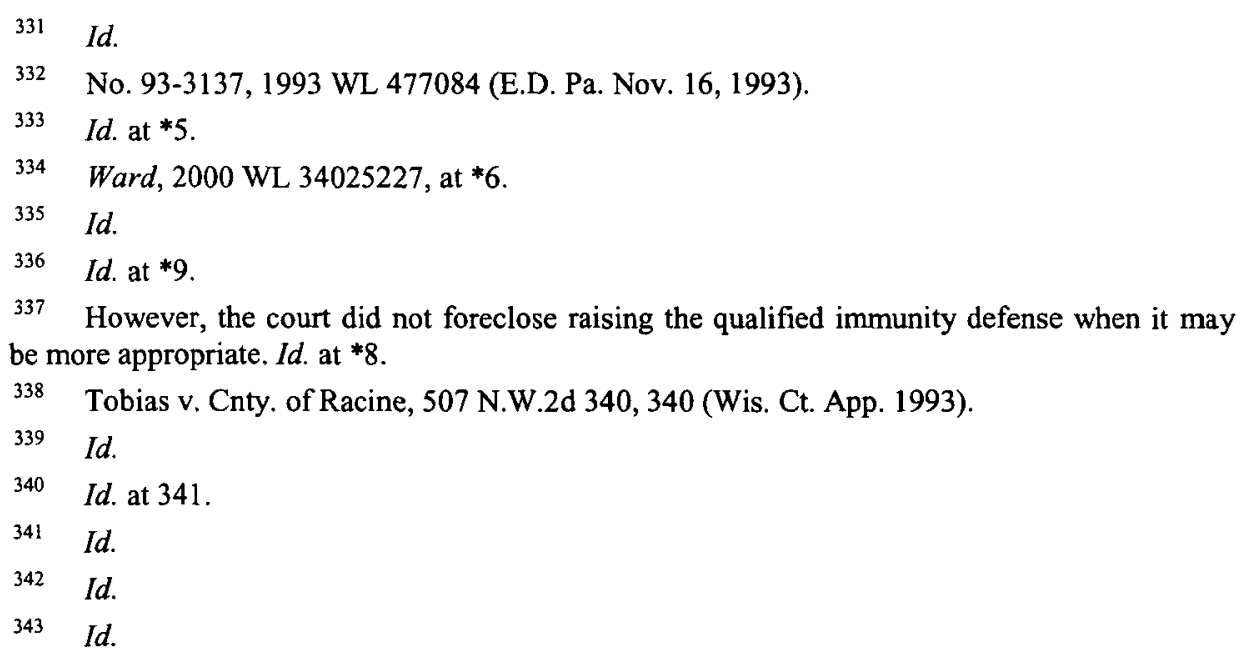


failed to issue a capias order" for the teenager's arrest. ${ }^{344}$ The court held that the injury was too remote because it was not foreseeable that a "third person would commit a crime against [the teenager] because of the opportunity created by the county's negligence." 345 The court, however, stated that the county was negligent in not issuing the capias because it should have been aware that it was unsafe for the teenager to be out in the streets. ${ }^{346}$ Although the crime was a superseding cause, the court left open the possibility for state liability in a runaway case of a child who was not even in custody of the state, but only receiving state services.

\section{The Foster Child's Right To Be Free from Harm Following Discharge-Analogy to State-Created Danger Cases}

No cases have been brought alleging constitutional violations for harms suffered by a foster child, or class of foster children, after official discharge from foster care. But an analogy can be made to the "state-created danger" cases, in which the government is held constitutionally liable for actions towards private citizens who are not in their custody, and are often less sympathetic, than foster children. ${ }^{347}$ The state-created danger doctrine was first developed by the Seventh Circuit in White v. Rochford ${ }^{348}$ and Bowers $v$. DeVito. ${ }^{349}$ That court held that the Constitution protects persons who, while not in state custody, are nevertheless placed by the state in a position of danger and then left defenseless. According to the Seventh Circuit, when the state, by its actions, throws a person in a "snakepit," the Fourteenth Amendment's guarantee of due process is triggered. ${ }^{350}$

Similarly, in Wood v. Ostrander, ${ }^{351}$ the Ninth Circuit held that police officers could be liable for the rape of the car's passenger after the police left her on the side of the road in a high crime area. Davis v. Brady ${ }^{352}$ also involved police stopping a drunk driver. There, the police were responsible for the drunk driver's injuries after the police left the driver with his keys, and the driver later

\footnotetext{
344 Id. A capias order is "an order to arrest and detain an individual for the purpose of guaranteeing a court appearance." THE LAW DICTIONARY, http://thelawdictionary.org/article/ what-is-a-capias-warrant/ (last visited Feb. 25, 2015).

345 Tobias, 507 N.W.2d at 342.

346 Id. at 340.

347 See Erwin Chemerinsky, The State-Created Danger Doctrine, 23 TouRO L. REV. 1 (2007).

348 White v. Rochford, 592 F.2d 381 (7th Cir. 1979).

349 Bowers v. DeVito, 686 F.2d 616 (7th Cir. 1982).

$350 \quad$ Id. at 618.

351 Wood v. Ostrander, 879 F.2d 583 (9th Cir. 1989).

352 Davis v. Brady, 143 F.3d 1021 (6th Cir. 1998).
} 
collided with another vehicle. ${ }^{353}$ The court, like the Ninth Circuit in Wood, held that it was the government that put this person in danger and the government should be held liable. ${ }^{354}$ Similarly, in Munger v. City of Glasgow, ${ }^{355}$ police were called to a bar when there was a dispute and ultimately kicked a man out of the bar and took away his keys. It was a cold night and he was dressed just in jeans and a t-shirt. ${ }^{356}$ The police would not let him back into the bar or his car. ${ }^{357}$ The man died of hypothermia. ${ }^{358}$ The court held that the government created the danger and the government was responsible for depriving his life without due process. ${ }^{359}$

Even pretrial detainees have such rights. In Paine v. Johnson, ${ }^{360}$ the guardian of the estate of the pretrial detainee, who allegedly suffered from bipolar disorder, brought suit against the city and city police officers. The plaintiff alleged civil rights violations in connection with the detainee's arrest and subsequent release from custody to a high risk situation, given her mental condition, in which she was ultimately raped. ${ }^{361}$ Police officers were denied summary judgment because fact issues existed as to whether the officer who released the detainee from custody violated the detainee's substantive due process rights under the Fourteenth Amendment. ${ }^{362}$ Significantly, the court held that many factors or conduct of two or more persons may operate at the same time, either independently or together, to cause injury or damage; in such case each may be the proximate cause of an injury, as required to establish liability under the Constitution. ${ }^{363}$ Moreover, the court held that legal causation is a fact-specific inquiry and involves consideration of time, geography, range of potential victims, and the nature of harm that occurred. ${ }^{364}$

Most relevant to foster children is Currier v. Doran. ${ }^{365}$ In Currier, a social worker transferred custody of a child from the mother to the father. ${ }^{366}$

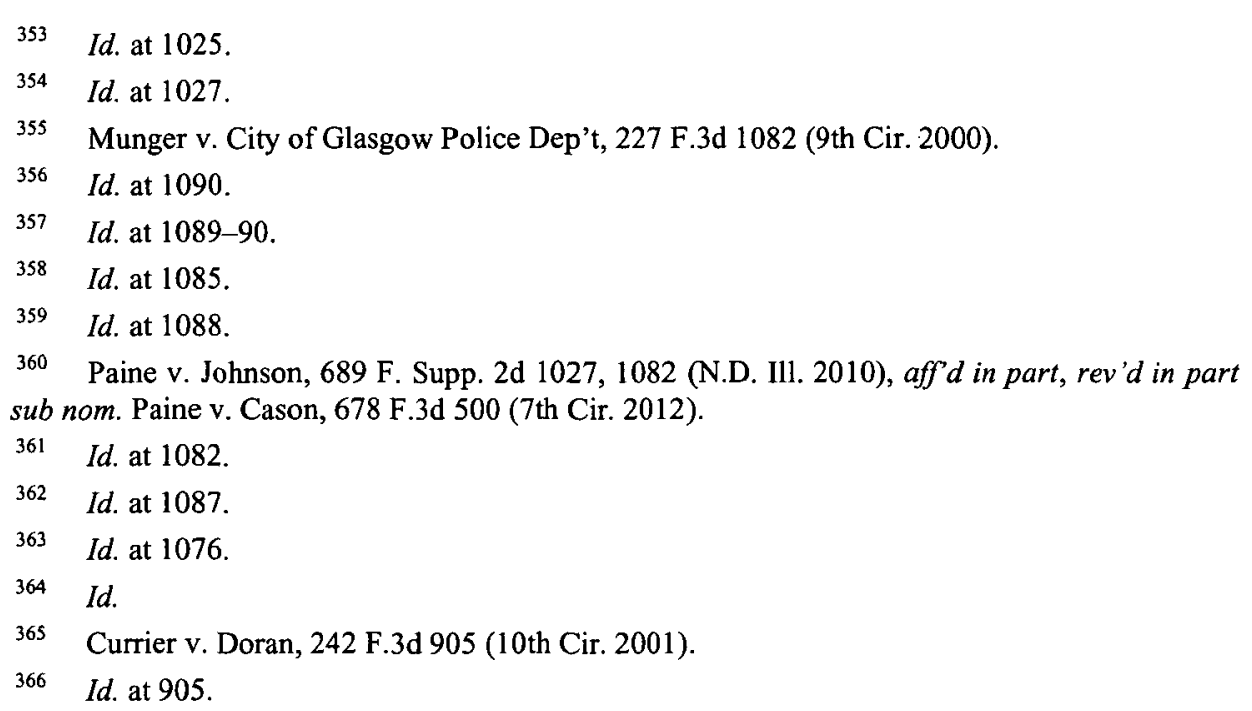


The father subsequently killed the child. ${ }^{367} \mathrm{~A} \S 1983$ suit was brought and the issue was whether the social worker could be held liable for state-created danger. ${ }^{368}$ The Tenth Circuit, finding the social worker liable under a deliberate indifference standard, held that the child "would not have been exposed to the dangers from [his] father but for the affirmative acts of the state [social worker]."369

The holdings of these state-created danger cases can be applied to foster children. The state creates inevitable dangers when it discharges youths to conditions in which they will obviously flounder. For example, states invariably release youths to homeless shelters with no supportive adults in their lives and no prospects for finding actual places to live. ${ }^{370}$ An 18-year-old girl, who has been discharged, with no job, to a shelter in a crime ridden area, where pimps are known to operate, could prove proximate cause and state responsibility if she becomes a victim of sexual exploitation.

\section{CONSTITUTIONAL REMEDY}

Now is the time for foster children to bring $§ 1983$ claims, whether individually or by class action, for the sexual exploitation they endure when missing from foster care or shortly after discharge. ${ }^{371}$ This is the only way to make state agencies and caseworkers pay attention and for the recent federal legislation to have any teeth. It is also essential, while there is a national spotlight on this issue, for courts to establish constitutional protections for runaway and discharged foster children.

\footnotetext{
367 Id.

368 Id.

369 Id. at 918.

370 See supra Part II; see also Homeless Youth, NAT'L COALITION FOR THE HOMELESS (June 2008), http://www.nationalhomeless.org/factsheets/youth.html; Proposed Class Action Settlement Averts the Danger of Homelessness for Young People Aging Out of Foster Care, LEGAL AID SOC'Y (Oct. 20, 2011), http://www.legal-aid.org/en/mediaandpublicinformation/ inthenews/proposedclassactionsettlementavertsthedangerofhomelessness.aspx ("'An alarming number of young people are being discharged from foster care into homelessness,' said Tamara Steckler, Attorney-in-Charge of the Juvenile Rights practice at The Legal Aid Society.").

371 Civil rights actions can be brought in federal and/or state court. State courts may properly hear $\S 1983$ cases pursuant to the Supremacy Clause of Article VI of the U.S. Constitution. The Supremacy Clause mandates that states must provide hospitable forums for federal claims and the vindication of federal rights. U.S. CONST. art VI, cl.2. This point was solidified in the Supreme Court decision of Felder v. Casey, 487 U.S. 131 (1988).
} 
Establishing legal precedent is particularly important because of the doctrine of qualified immunity from $\S 1983$ claims. ${ }^{372}$ Qualified immunity protects government officials from individual liability under $\S 1983$ for actions taken while performing discretionary functions, unless their "conduct violates clearly established statutory or constitutional rights of which a reasonable person would have known." ${ }^{373}$ Before liability will attach, "the contours of the right must be sufficiently clear that a reasonable official would understand that what he is doing violates that right." $" 374$

The right can be "sufficiently clear" without Supreme Court or other holdings specifically on point. "[A] Supreme Court decision is not absolutely imperative before a law may be considered "clearly established." "'375 In People of Three Mile Island v. Nuclear Regulatory Commissioners, ${ }^{376}$ the Third Circuit addressed the issue of how "clearly established" a law must be in order for it to defeat qualified immunity. A clearly establish law can simply mean that "officials apply general, well developed legal principles.... [W]e cannot expect executive officials to anticipate the evolution of constitutional law, neither can we be faithful to the purposes of immunity by permitting such officials one liability-free violation of a constitutional or statutory requirement." $" 377$

"General legal principles" regarding constitutional rights can emanate from a variety of courts with jurisdiction to hear constitutional claims. ${ }^{378}$ Federal district and circuit courts, as well as state courts, can establish the principle for their respective lower courts. ${ }^{379}$ This is why we need to establish precedent now by bringing cases. Using the right to be free from harm and

\footnotetext{
372 See Gann v. Schramm, 606 F. Supp. 1442, 1447 (1985) ("There are four prerequisites to constitute a valid claim under section 1983; that is, (1) the defendants must have acted under color of state law; (2) the conduct must have implicated a life, liberty or property interest; (3) a deprivation of the particular interest; and (4) the deprivation was without due process of law.").

373 Id. at 1449 (quoting Harlow v. Fitzgerald, 457 U.S. 800, 818 (1982)).

374 Anderson v. Creighton, 483 U.S. 635, 640 (1987).

375 Gann, 606 F. Supp. at 1449.

376 Three Mile Island v. Nuclear Regulatory Comm'rs, 747 F.2d 139, 144 (3d Cir. 1984).

377 Id. at $144-45$.

378 Gann, 606 F. Supp. at 1449.

379 See, e.g., id. ("A ruling of the Third Circuit is enough for law to be considered "clearly established."'); Dehorty v. New Castle Cnty. Council, 560 F. Supp. 889 (D. Del. 1983). This district has also noted that the rulings of three Courts of Appeals (not including the Third Circuit) are sufficient for a legal principle to be considered well established. Masjid Muhammad-D.C.C. v. Keve, 479 F. Supp. 1311, 1321 (D. Del. 1979). "[T] he only difference [in court rulings] is in the standard applied to determine when the violation of that right infringes upon fourteenth amendment rights." Gann, 606 F. Supp. at 1450. "Although the Third Circuit decision alone may not have been enough to render the legal principle clearly established,... [t]hree circuits as well as a number of district courts had acknowledged such a right." Id. (citations omitted).
} 
state-created danger doctrines discussed in Part IV, we can begin to develop jurisprudence for missing and discharged foster children. ${ }^{380}$

\section{CONCLUSION}

Youths aging out of foster care are one of the most vulnerable populations in this country. That we should allow them to transition from foster care to dire outcomes, only occasionally holding their custodians to minimal constitutional standards, is unacceptable. The sexual exploitation of adolescents involved with the child welfare system has recently gained much needed attention. The Preventing Sex Trafficking and Strengthening Families Act, discussed in Section III.B, will also help establish the right of missing and discharged foster children to be free from sexual exploitation. The Act must be publicized, the records kept and reported, and the training disseminated. This will be hard work, especially at the front lines. As CWLA, the only group to publish a handbook on working with youths missing from care ${ }^{381}$ emphasizes,

those who work with children in care must proactively... prevent missing-from-care episodes, rather than merely reacting once a child has gone missing . . . successful prevention efforts are built on sound administration; quality supervision; effective training; and frequent contacts between workers and caregivers, works and children in care, and children and their birth families and relatives. ${ }^{382}$

The problem, however, has gone on far too long to wait for the legislation to trickle down to front line caseworkers. Legislation targeted at adolescents in foster care, going back to 1999, has not put an end to the harsh

380 An example of a court using a general legal principle established by federal courts to apply to another context is also found in Gann: "Further support that this right to safety was clearly established may be found in some of the eighth amendment prison cases." 606 F. Supp. at 1450 (emphasis added). In Estelle v. Gamble, the Supreme Court noted that "deliberate indifference to serious medical needs of prisoners" violates the Eighth Amendment. 429 U.S. 97, 104 (1976). Individuals who are involuntarily confined in a mental hospital certainly should have no less rights than a prisoner. N.Y. State Ass'n for Retarded Children, Inc. v. Rockefeller, 357 F. Supp. 752, 764 (E.D.N.Y. 1973). Indeed, "[i]t would be anomalous to find that the right to a secure environment, which federal courts have often intervened to protect in the context of penal institutions, did not extend to facilities for the mentally retarded." Romeo v. Youngberg, 644 F.2d 147, 162 (3d Cir. 1980). Thus, in December 1980, the right to a safe environment for those involuntarily committed to mental institutions had received wide acceptance by the courts. The right was a general, well developed legal principle that officials at a state mental hospital should have been applying daily. If they did not do so, they have forfeited the privilege of official immunity.

381 CWLA, supra note 21 , at $\mathrm{X}-\mathrm{XV}$.

$382 \quad$ Id. at 9. 
Cecka: The Civil Rights of Sexually Exploited Youth in Foster Care

realities of aging out. Statutes and rhetoric can only do so much. Those legally in charge of young people must be accountable for protecting them. Sexual exploitation should not be an inevitable outcome of the United States foster care system. 
West Virginia Law Review, Vol. 117, Iss. 3 [2015], Art. 13 